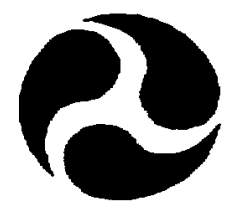

U.S Department of Transportation

Research and Special Programs Administration

\title{
A Primer on Consumer Marketing Research: Procedures, Methods, and Tools
}

March 1994

Prepared by:

Jane E. Lappin, EG\&G Dynatrend

Paula Figoni, Simmons College Graduate School of Management

Suzanne M. Sloan, EG\&G Dynatrend

Economic Analysis Division

John A. Volpe National Transportation Systems Center

Cambridge, Massachusetts

Prepared for:

Office of Policy Development

Federal Highway Administration

Washington, D.C. 


\section{FOREWORD}

The following is one of a series of papers developed or produced by the Economic Analysis Division of the John A. Volpe National Transportation Systems Center as part of its research project looking into issues surrounding user response and market development for selected Intelligent VehicleHighway Systems (IVHS) products or services. The project, sponsored by the Federal Highway Administration's Office of Policy Development, was one part of FHWA's 1992 Institutional Issues Program entitled -- "Public Acceptance and Markets for Various Consumer IVHS Services". John O'Donnell of the Volpe Center and James March of FHWA served as Project Managers for their organizations.

The objective of the Volpe Center project was to better understand factors affecting the development and deployment of selected advanced traveler information products and services (ATIS). The Center addressed the objective by examining the development of markets for selected ATIS-related products and services and reviewing factors affecting the public acceptance and user response to existing traffic information services.

Deployment of many of the newly emerging and projected IVHS products and services will depend upon consumers purchasing and otherwise choosing to make use of advanced traffic and travel information products and services. Through four different projects, each with a distinctive approach to understanding consumer response and market demand, the Volpe Center explored the question: Given the opportunity to buy a product or subscribe to a service that promises to deliver traveler information, will the consumer perceive that there is sufficient benefit to be gained to justify the investment?

The Volpe Center and FHWA jointly conducted a workshop in the Fall of 1992 to discuss issues involved with assessing the market for IVHS products and services. The objectives of the workshop were to help define a research program which would address measuring user acceptance and response to ATIS products and services and the role market research plays in understanding emerging markets for new or unknown products and services.

The results of the workshop are reflected in the four research tasks initiated as part of this program and the seven papers which comprise it. The four task areas are summarized below. Copies of the papers will be provided upon request to the Volpe Center. 
TASK 1. Industry Methods for Assessing Consumer Response to New Products/ Services

The first project was designed to answer the question of how consumer response and market demand are measured in the commercial sector, where these market demand questions are fundamental to the survival and success of the business. This project has two parts. The first is a primer on how consumer marketing research is done in the commercial sector. The second presents three case studies that examine how three current high-technology communications and travel products applied marketing research in preparation for market release.

Report 1A. A Primer on Consumer Marketing Research: Procedures, M ethods, and Tools

The Volpe Center developed a marketing research primer which provides a guide to the approach, procedures, and research tools used by private industry in predicting consumer response. The final two chapters of the primer focus on the challenges of doing marketing research on "revolutionary" products, or those products which the consumer has had no direct experience with, as is the case with most IVHS products and services. This primer was designed to provide the non-marketing researcher with a good understanding of how this particular type of human behavior research is pursued.

Report 1B. Case Studies of M arket Research for Three Transportation Communications Products: Electronic Toll Collection, Advanced $\checkmark$ ehicle Information and Location, and Cellular Telephones

Three case studies were undertaken to demonstrate the application of marketing research to products which are analogous to ATIS products and services, to learn from the market experience of these three ATIS-analogous products any lessons which rnight be applicable to future ATIS research, and also to demonstrate the uncertainty - despite good research design and assumptions - of marketing research predictions. The case studies were written by Thomas Parish of Arthur D. Little, Inc.

TASK 2. ATIS M arket Research: A Survey of $O$ perational Tests and U niversity Research

The challenge of marketing research is much more difficult where the consumer has not had direct personal experience using the proposed product in daily life. The operational tests provide an excellent opportunity for gathering consumer response and market demand information from "experienced" consumers. The Volpe Center team surveyed the operational 
tests that were extant or complete (as of 8/93) to learn whether any consumer response/ market demand information had been collected and analyzed. The survey was extended to include government-sponsored university research projects so as to provide a more complete overview of the current national research program in relation to this question.

\section{TASK 3. A M arket A nalysis of the Commercial Traffic Information Business}

What kind of traffic information is available to consumers right now? How do consumers respond to current offerings? What are the market/ economic fundamentals that underlie this market?

The traffic information services business is well-established and a study of its market fundamentals yields insight into consumer response to ATIS as well as providing useful information to policy makers who are considering the future role of government in this arena. This report describes how traffic information is gathered, processed, packaged, wholesaled, and retailed on the variety of platforms which are available on the market today.

\section{TASK 4. Laboratory Simulation of ATIS for Testing Drivers' Response}

This project was formulated to explore the feasibility of enhancing existing laboratory or PC-based driver decision simulators which have the ability to gather revealed preference data and test drivers' decisions in the presence of traffic information. Such simulators, it was hypothesized, could supplement operational tests as a source of consumer response and market demand data. The work was performed at MIT under the leadership of Professor Moshe BenAkiva.

Report 4A. State of the Art of ATIS D river Simulators

The project was divided into three parts. The first, covered in this report, reviewed all existing driver simulators to learn whether any were sufficiently sophisticated to be used, as is, to reliably test drivers' response to traffic information.

\section{Report 4B. A Review of ATIS Operational Tests}

The design of any laboratory-based simulator is based upon a model of how individuals respond to stimulus, in this case ATIS products. To construct a model, one must first study the natural behavior of live subjects in an actual ATIS driving situation. Report $4 \mathrm{~B}$ looks to the existing and completed ATIS 
operational tests to learn whether data has been produced that is suitable for the purposes of developing or improving ATIS models.

Report 4C. A M odeling Framework for U ser Response to ATIS

This report focuses on the information required to support the development of a modeling framework for driver response to ATIS. In it, the author identifies the stages of user response to ATIS, outlines the key factors associated with each decision, and discusses the data which would be required to complete the model, and thus construct a reliable, durable driver simulator. 


\section{Foreword}

\section{TABLE OF CONTENTS}

1. INTRODUCTION $\ldots \ldots \ldots \ldots \ldots \ldots \ldots \ldots \ldots \ldots \ldots$

2. MARKETING RESEARCH PROCEDURES $\ldots \ldots \ldots \ldots \ldots \ldots$

3. MARKETING RESEARCH METHODS AND TOOLS $\ldots \ldots \ldots .9$

Research Methods $\ldots \ldots \ldots \ldots \ldots \ldots \ldots \ldots \ldots \ldots \ldots \ldots$

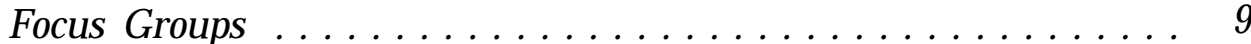

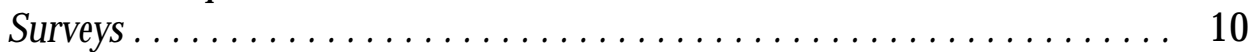

Controlled Experiments ................... 11

Secondary Research ........................ 11

Questionnaires - The Primary Measurement Technique ...... 13

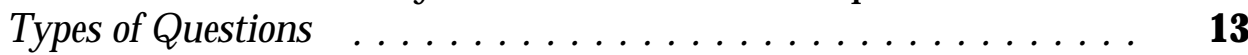

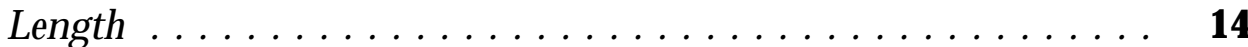

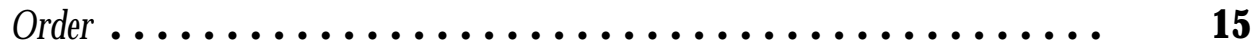

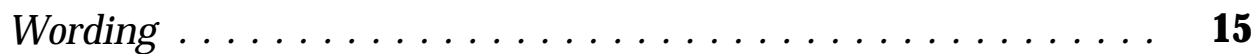

Preliminar y Testing ..................... 16

Sample Design $\ldots \ldots \ldots \ldots \ldots \ldots \ldots \ldots \ldots \ldots \ldots \ldots \ldots \ldots 16$

Choosing fhe Right Sampling Frame $\ldots \ldots \ldots \ldots \ldots \ldots \ldots 16$

Sampling Procedures ....................... 16

Sample Size ........................ 17

Interviewing Methods $\ldots \ldots \ldots \ldots \ldots \ldots \ldots \ldots \ldots \ldots \ldots \ldots$

Telephone Surveys . . . . . . . . . . . . . . . . . . . . . 18

Mail Surveys ............................ 19

Personal Interviews ...................... 20

Data Analysis ......................... 21

Data Tabulation ....................... 21

Difference Tests ......................... 21

A ssociation Tests ...................... 22

4. MARKETING RESEARCH LIMITATIONS AND SOURCES OF

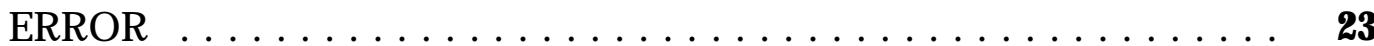

Limitations of Marketing Research $\ldots \ldots \ldots \ldots \ldots \ldots \ldots 23$

Sources of Error $\ldots \ldots \ldots \ldots \ldots \ldots \ldots \ldots \ldots \ldots \ldots \ldots \ldots \ldots$ 
Marketing Research Steps in the Introduction of a New

Product......................... 27

Step I. Product Development .................... 27

Step 2. $M$ arket A nalysis . . . . . . . . . . . . . . 28

Step 3. Concept Testing . . . . . . . . . . . . . . . . . . 29

Step 4. $\quad M$ arket Segmentation . . . . . . . . . . . . . . 31

Step 5. Product, Pricing, and Advertising Testing ......... 32

Step 6. Sales Forecasting . . . . . . . . . . . . . . . 34

Step 7. Product Introduction .................. 35

Step 8. Product Performance M onitoring . . . . . . . . . . . . 35

6. BRINGING INNOVATIVE PRODUCTS AND SERVICES TO

MARKET $\ldots \ldots \ldots \ldots \ldots \ldots \ldots \ldots \ldots \ldots \ldots \ldots \ldots \ldots \ldots \ldots \ldots \ldots$

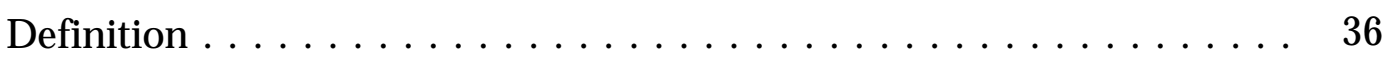

Marketing Research Challenges . . . . . . . . . . . . . 36

Research Approach $\ldots \ldots \ldots \ldots \ldots \ldots \ldots \ldots \ldots \ldots \ldots \ldots \ldots$

Product Development ..................... 38

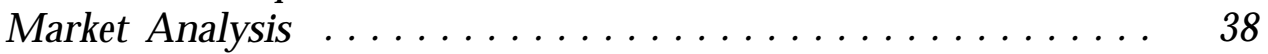

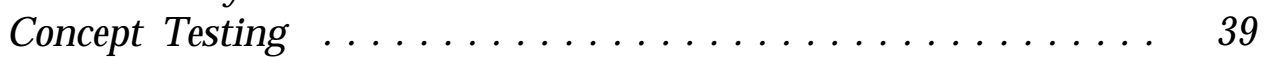

M arket Segmentation ...................... 39

Product, Pricing, and Advertising Testing ............. 39

Sales Forecasting/Predicting Product Diffusion ........... 41

Product Introduction/Post-Introduction M onitoring ......... 42

7. SUMMARY $\ldots \ldots \ldots \ldots \ldots \ldots \ldots \ldots \ldots$

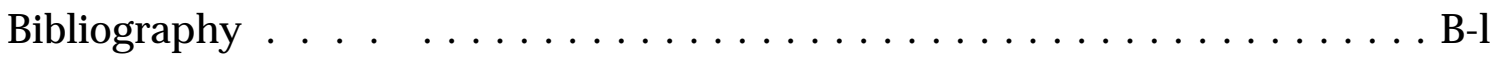

Appendix A: Marketing Research References, Directories, and Guides . . A-I Appendix B: Examples of Structured Questions Used in Questionnaires . . A-3 A ppendix C: Guidelines for Writing Survey Questions . . . . . . . . . . A-4 A ppendix D: Comparison of Simulated and Full-scale Test Markets ... A-5 


\section{LIST OF EXHIBITS}

Exhibit 1: $\quad$ Six Situations When Marketing Research Can Help

Exhibit 2: Ten Situations When Marketing Research May Not Help

Exhibit 3: Steps In Planning A Market Research Project

Exhibit 4: $\quad$ Sequence of Types of Research Objectives Over the Life of a Project

Exhibit 5: Research Methods and Sources of Data for Different Research Objectives

Exhibit 6: Designing a Sample

Exhibit 7: Processing and Analyzing the Data

Exhibit 8: Laboratory and Field Experiment Features

Exhibit 9: $\quad$ Examples of Syndicated Data Sources

Exhibit 10: Syndicated Data Sources for Different Industries

Exhibit 11: Types of Questions Categorized by Function

Exhibit 12: Rating of Data Collection Methods on Different Factors

Exhibit 13: Types of Errors in Marketing Research Projects

Exhibit 14: Marketing Research Steps in the Introduction of a Product

Exhibit 15: Factors to Consider in Evaluating Market Potential 


\section{Introduction}

Industry measures consumer behavior with the goal of ascertaining whether a product or service is likely to produce sufficient market demand to justify investment in production and distribution. Its methods are generally pragmatic and designed to limit risk while optimizing profits. Marketing research can reduce the uncertainty and risk that accompany the introduction of new products into the marketplace.

Ford's consumer testing of the Taurus in the 1980s illustrates how marketing research can pay off. Ford left little to chance, spending over two years on its most ambitious series of marketing studies up until that time, including 100,000 miles of driving tests with drivers of all ages (Mitchell, 1986). The Taurus was an immediate success, and today it is America's best-selling automobile.

Companies ignore the benefits of doing marketing research at their peril. IBM, for instance, seemed more concerned that its first true consumer product, the PCjr, did not cannibalize sales of the company's other computers than about designing a product consumers were interested in and could afford. IBM conducted only a few tests — primarily to ascertain whether consumers could operate the computer easily. No tests were run to determine whether the PCjr had the right features for the consumer (Anonymous, 1984). Ultimately, the product failed dismally.

Marketing research can be quite expensive. Companies must weigh the benefit of increased market information against the cost of conducting research in relation to the amount of profit that the product will generate. A series of focus groups can cost anywhere from $\$ 5000$ to $\$ 12,000$. A full-scale test market can cost upwards of $\$ 3$ million. Each year, marketing research expenditures in the U.S. total $\$ 3$ billion to $\$ 4$ billion (Boyd, 1990).

Marketing research takes time. Planning and conducting focus groups, and analyzing and summarizing the results can take six weeks or longer; test markets often run a year or more. Obviously, the costs must be weighed against the benefits. Exhibits 1 and 2, following, summarize times when marketing research might be useful and times when it might be inappropriate.

It should be noted that, for the purposes of this paper, a distinction is made between marketing research and market research. Marketing research is done to learn how best to develop and expand a product's market; market research is research on the market itself, and includes an analysis of such market factors as government regulations, established competitors, and trends in consumer behavior. Market research, or analysis, is frequently a component of marketing research. 
The remainder of this document is divided into sections. Sections 2 through 4 address the mechanics of structuring a marketing research program. Section 2 summarizes marketing research procedures, Section 3 provides an overview of research methods (e.g., focus groups, surveys). This section also discusses the primary role of questionnaires and the significance of sample design, data collection methods, and various analytical techniques that marketing researchers use to estimate market opportunities. Section 4 briefly examines the limitations of marketing research and the most common mistakes that are made during marketing studies-skewing data and producing flawed results, if not caught in time.

For the reader with a limited amount of time, Sections 5 and 6 build on the methodology defined in earlier sections and describe the process of bringing a product to market. Section 5 provides a framework for conducting marketing research activities and distinguishes between conducting marketing research for a new product as opposed to an "innovative", or revolutionary product. It should be noted that most IVHS products fall into the category of "innovative" product. Section 6 discusses the challenges of assessing the market for an innovative product.

The Appendixes include a list of marketing research resources for further reading (Appendix $A$ ); sample questionnaire material (Appendix $B$ ); guidelines that will help in survey question design (Appendix C); and a comparison of simulated and full-scale test markets (Appendix D).

\section{Exhibit 1. Six Situations When Marketing Research Can Help}

- You lack the necessary information to make a marketing decision

- You' re weighing alternatives and aren't sure which one to choose

- When there is conflict within the organization over some policy, objective, or strategy

- You detect symptoms of a problem, such as declining market share

- A marketing program is going well, and you want to know why

- When you undertake something different: new product, revised price, new market segment

Source: Adler, 1980 


\section{Exhibit 2. Ten Situations When Marketing Research May Not Help}

- You honestly know what you need to know without research

- The information already exists

- Time is an enemy

- Conducting research would tip your hand to a competitor

- A test doesn't represent future conditions

- The cost of research would exceed its value

- The budget is insufficient to do an adequate job

- Research findings would not affect the product's introduction

- The problem is unclear, and the objectives are vague

- The research is not technically feasible

Source: Adler, 1980 


\section{Marketing Research Procedures}

\section{Overview}

Each marketing research project has its own challenges and approach, but researchers tend to use the same general steps in designing any research project (Exhibit 3). Because the steps are closely related, a change made at one stage of the process often requires that revisions be made to other stages. Once the data is collected, however, no further revisions are possible. The researcher should therefore, plan the entire research project before any data is actually collected.

Exhibit 3. Stem in Planning a Marketing Research Process

\begin{tabular}{l|c|} 
Step 1 & $\begin{array}{c}\text { Define research objectives and information } \\
\text { needs }\end{array}$ \\
Step 2 & Evaluate the need for research; write proposal \\
\cline { 2 - 2 } & \\
Step 3 & Determine research design \\
Step 4 & Develop data collection procedure \\
Step 5 & Design sampling plan \\
\cline { 2 - 2 } & \\
Step 6 & Collect data \\
Step 7 & Process and analyze data \\
&
\end{tabular}

\section{Step 1. D efining Research 0 bjectives and Information Needs}

A well-designed marketing research project starts with clearly defined research objectives. The specific information needed to meet those objectives must be spelled out at project onset. For instance, a telecommunications company seeking to develop an advertising campaign to increase sales of its services determines that its research objective is to obtain an accurate profile of contemporary cellular phone users. Specific information that would have to be gathered to meet this objective likely would include: 
- $\quad$ Age, income, and gender of cellular phone users.

- $\quad$ Frequency of cellular phone use.

- When most commonly used?

- Where most commonly used (car? building?)

- $\quad$ Primary reasons for use (business? contact with family members?)

- $\quad$ Likes and dislikes of current phone model and service.

This is descriptive research. Other types of research are exploratory causal or predictive, and performance-monitoring. Research on likely causes for decreased sales is an example of exploratory research since the objective is broad and vague.

Causal research adds value to descriptive data by identifying and quantifying cause-and-effect relationships. Causal research is also sometimes called "predictive" research, since it often serves to predict how certain marketing decisions will affect sales.

Performance-monitoring research objectives include monitoring market share, sales, and profits, particularly following the introduction of a new product or a change in marketing strategy.

Although these research categories are not definitive and somewhat overlapping, they are useful in clarifying research objectives, and - later - in defining the appropriate research design. Often, the categories follow a sequence throughout the life of a project, with the research objectives becoming more specific and focused, and the research methods increasing in cost and complexity, as the research team moves on from exploratory work. Exhibit 4 illustrates a typical sequence of types of research objectives over the life of a project.

Exhibit 4. Sequence of Types of Research Objectives over the Life of a Project

\begin{tabular}{c|c|c|}
\hline Exploratory & Descriptive \\
Identify a new & $\begin{array}{c}\text { Describe } \\
\text { consumer } \\
\text { purchasing } \\
\text { behavior }\end{array}$ \\
\hline
\end{tabular}

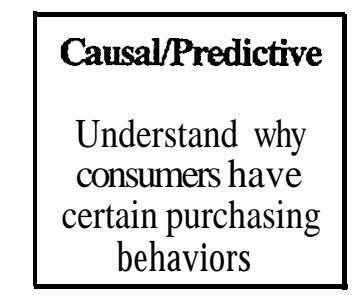
Performance Monitoring
Compare actual market activity against plan




\section{Step 2. Write proposal}

Whether working with an outside contractor or an internal marketing research department, an outline of the research project should be proposed in writing and agreed on. The initial proposal must define the marketing problem or opportunity, the research objectives and information needs, and how the information is to be used. More detailed proposals can clarify the remaining steps in the research process, including the method and design of the research, an estimate of project expenses, and expected benefits.

In this way the researcher arrives at an understanding of the problems and needs of the decision-maker. Upper management should sign off on the proposal, as should those affected by the research, to ensure buy-in. In many companies, a research proposal that addresses product design might include a sign-off from $R \& D$; a proposal that addresses trade promotions might include sign-off from sales.

\section{Step 3. D etermine Research D esign}

Certain approaches (exploratory, descriptive, causal/ predictive, performancemonitoring) are commonly associated with certain research objectives. Exhibit 5 outlines common research designs, methods, and sources of data for typical research objectives. The selected approach should be consistent with the research objective and facilitate accurate and economical data collection and analysis.

\section{Step 4: D evelop the D ata Collection Procedure}

Data collection procedures include store audits, direct observation. of respondents as they use a product or service, or use of a questionnaire to ink-view respondents. Most marketing research studies involve a questionnaire, which must be tied to the research objectives/data needs stated back in step 1. 
Exhibit 5. Research Methods and Sources of Data for Different Research Objectives

\begin{tabular}{|c|c|c|c|}
\hline $\begin{array}{l}\text { Type of } \\
\text { Research }\end{array}$ & $\begin{array}{c}\text { Examples of Research } \\
\text { Objectives }\end{array}$ & Research Methods & Data Sources \\
\hline $\begin{array}{l}\text { Exploratory } \\
\text { (qualitative) }\end{array}$ & $\begin{array}{l}\text { Identify new opportunities or } \\
\text { problems } \\
\text { Provide background information on } \\
\text { a topic } \\
\text { Generate hypotheses that will be } \\
\text { further tested quantitatively } \\
\text { Gain perspective on a complex } \\
\text { issue } \\
\text { Generate information helpful in } \\
\text { structuring questionnaires }\end{array}$ & $\begin{array}{l}\text { Focus-group interviews } \\
\text { Indepth interviews } \\
\text { Case analyses }\end{array}$ & $\begin{array}{l}\text { Respondents who have } \\
\text { experience with the } \\
\text { product, service, or } \\
\text { problem under study. } \\
\text { Secondary sources: U.S. } \\
\text { census data, syndicated } \\
\text { consumer studies, trade } \\
\text { journals }\end{array}$ \\
\hline $\begin{array}{l}\text { Descriptive } \\
\text { (quantitative) }\end{array}$ & $\begin{array}{l}\text { Determine buyer perceptions of } \\
\text { product characteristics } \\
\text { Describe the characteristics of } \\
\text { consumers, competitors, and the } \\
\text { market } \\
\text { Describe consumer purchasing } \\
\text { behavior }\end{array}$ & Survey & $\begin{array}{l}\text { Respondents who represent } \\
\text { the population under study } \\
\text { Secondary sources: U.S. } \\
\text { Census data, syndicated } \\
\text { consumer studies, trade } \\
\text { journals }\end{array}$ \\
\hline \multirow[t]{2}{*}{$\begin{array}{l}\text { Causal/predictive } \\
\text { (quantitative) }\end{array}$} & \multirow{2}{*}{$\begin{array}{l}\text { Understand behaviors that cause } \\
\text { changes in market activity } \\
\text { Understand why consumers hold } \\
\text { certain attitudes, perceptions, or } \\
\text { behaviors } \\
\text { Predict market activity before a } \\
\text { product is introduced or a } \\
\text { marketing strategy is modified }\end{array}$} & $\begin{array}{l}\text { Laboratory experiment: } \\
\text { survey or simulated test } \\
\text { market }\end{array}$ & $\begin{array}{l}\text { Respondents who represent } \\
\text { the population under study }\end{array}$ \\
\hline & & $\begin{array}{l}\text { Field experiment: test } \\
\text { market or controlled test } \\
\text { market panel }\end{array}$ & $\begin{array}{l}\text { Market that represents the } \\
\text { population under study }\end{array}$ \\
\hline $\begin{array}{l}\text { Performance } \\
\text { monitoring } \\
\text { (quautitative) }\end{array}$ & $\begin{array}{l}\text { Compare actual market activity } \\
\text { against plan }\end{array}$ & Market audit & $\begin{array}{l}\text { Syndicated market study } \\
\text { based on scanner data or } \\
\text { physical audits }\end{array}$ \\
\hline
\end{tabular}




\section{Step 5. D esign the Sample}

Samples are intended to represent a population of consumers; thus emphasis should be on selecting appropriate sample members to represent the population. The selection process is summarized in Exhibit 6. Four tasks must be accomplished before actual physical selection of the sample can occur. First, clearly define the target population. The defined population should be related to the product being tested or the market being explored.

Exhibit 6. Designing a Sample

\begin{tabular}{|c|c|c|c|c|}
\hline Step 1 & Step 2 & Step 3 & Step 4 & Step 5 \\
\hline $\begin{array}{l}\text { Define the } \\
\text { population }\end{array}$ & $\begin{array}{l}\text { Identify the } \\
\text { sampling } \\
\text { frame }\end{array}$ & $\begin{array}{l}\text { Determine } \\
\text { the sample } \\
\text { size }\end{array}$ & $\begin{array}{l}\text { Select a } \\
\text { sampling } \\
\text { procedure }\end{array}$ & $\begin{array}{l}\text { Select the } \\
\text { sample }\end{array}$ \\
\hline
\end{tabular}

Source Kinnear, 1991

\section{Step 6. Collect the D ata}

Actual data collection is a pivotal step in the marketing research process, both because the potential for error is high, and because it is expensive to do. Properly executing Steps 1 through 5, testing the questionnaire beforehand, and monitoring the field work are the best ways to ensure that this penultimate step is completed properly and cost-effectively.

\section{Step 7. Process and A nalyze the D ata}

Exhibit 7 depicts the tasks involved in processing and analyzing data. The first task, editing, entails inspecting and correcting any omissions, errors in recording, or obviously wrong answers. Coding involves categorizing the raw data and assigning numerical codes to the categories (to expedite data analysis). Tabulation simply involves counting the number of cases that fall into the various categories. Finally, additional analyses, such as crosstabulation, regression, or factor analysis are completed, as needed.

Exhibit 7. Processing and Analyzing the Data

Step 1.

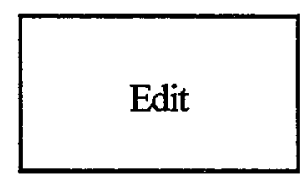

Step 2.

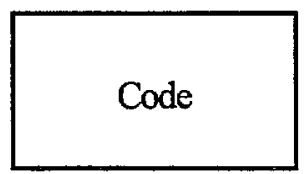

Step 3.

Step 4.

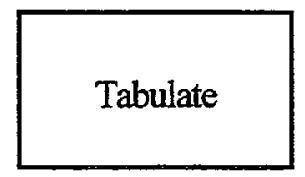

Complete additional analyses 


\section{Marketing Research Methods and Tools}

There are four primary methods of conducting marketing research: focus groups, surveys, controlled experiments, and secondary research. Depending upon the marketing research objectives, each method utilizes a different combination of questionnaires, data collection, and analytical techniques in order to "sample" the population for opinions. Proper sample selection and design of surveys is critical to ensure valid results from what is often a substantial investment in time and money. Proper survey/ questionnaire design also allows for a wider variety of techniques to be applied when analyzing the collected data.

Research Methods

Focus Groups

A popular exploratory technique, focus-group research usually involves a halfdozen to a dozen consumers brought together to discuss a given topic. Focus groups are used when in-depth probing is needed, or when a focussed discussion is needed to develop new ideas. Focus groups are often used to gather information about how a product is used or perceived in preparation for the development of a survey questionnaire. This form of qualitative research is relatively inexpensive, fast, and flexible compared to individual interviews or other, more conclusive, quantitative methods.

Features of successful focus-group research include:

The preparation, beforehand, of a moderator's discussion guide, with information on the objectives of the study, specific topics to probe, and the general sequence of questions.

The presence of a moderator who is able to stimulate discussion and direct it toward areas that will provide fruitful insights for subsequent analysis.

Group members selected to be as homogenous as possible. This permits clearer comparisons among groups (useful in market segmentation).

- $\quad$ Group members who have been carefully screened to eliminate those with insufficient exposure to the subject at hand.

One or more groups representing each market segment under study. 
Group sessions lasting long enough for the group to build rapport and explore the discussion topic adequately (usually 90 minutes to two hours).

Focus groups generally convene in well-equipped facilities (e.g., audiovisual equipment, two-way mirrors that allow market researchers to observe the discussion without disturbing the participants).

Focus group sessions are not foolproof. Probably the most common reason for a session to fail is when one person dominates discussion. It takes a skilled moderator to control such individuals and maintain an atmosphere that encourages free expression and lively and thoughtful discussion.

Surveys

Because focus group data is not necessarily valid statistical data, and because the opinions of one (or more) groups cannot be taken as a consumer mandate, most marketing research relies on descriptive surveys of consumers as one of the ways to produce more conclusive and dependable quantitative information.

In a survey, respondents are questioned on their attitudes and behavior; the emphasis is on generating summary statistics that:

Describe characteristics that differentiate one consumer group from another.

Estimate the proportion of people in the population who think or behave in a certain way.

Survey designers must be sure the research objectives are clearly stated. Vague or broad objectives may require exploratory research to define the problem more clearly (Churchill, 1988). To ensure that the survey addresses the research objectives, the survey designers must specify beforehand which objective or informational need each question addresses and the reason it is in the study.

A survey merely describes how things are at a given moment. Often, however, the survey becomes the basis for market predictions. This is especially risky if any significant time elapses between study and product introduction; consumers can have fickle tastes.

Furthermore, surveys provide only descriptions of relationships. A survey of the marketplace might suggest that a relationship exists between pricing and sales volumes of competitive offerings. This might be useful information, but 
it does not prove that pricing caused the differences in sales volumes, or that lowering prices will increase sales.

\section{Controlled Experiments}

Controlled experiments are another method of quantifying data beyond surveys and focus groups. Controlled experiments involve controlled changes in one or more variables, and observation of the effects. For example, if prices are systematically varied and all else held constant, changes in sales volumes can be readily measured.

Controlled experiments take place in the laboratory or the field. Exhibit 8 compares the most important features of these two approaches.

\section{Exhibit 8. Laboratory and Field Experiment Features}

\begin{tabular}{|l|l|l|}
\cline { 2 - 3 } \multicolumn{1}{c|}{} & \multicolumn{1}{c|}{$\begin{array}{c}\text { Laboratory } \\
\text { Experiments }\end{array}$} & \multicolumn{1}{c|}{$\begin{array}{c}\text { Field } \\
\text { Experiments }\end{array}$} \\
\hline Control over variables and external conditions & High & Low \\
\hline cost & Low & High \\
\hline Time & Shorter duration & Longer duration \\
\hline Ability to simulate real market conditions & Low & High \\
\hline
\end{tabular}

Secondary Research

Because marketing research generally requires substantial time and money, it makes sense to determine whether information is already available from "secondary" sources (i.e., relevant market data that is al ready published and available). Such sources include many business and consumer publications, company files, U.S. Census data, syndicated data, and purchasable off-the-shelf studies. Currently many off-the-shelf studies and surveys are listed in FINDEX, a comprehensive listing of over 12,000 market and business studies (Appendix A).

Syndicated studies are large, often complex, ongoing studies undertaken by marketing research firms and sold separately to many clients. Syndicated studies cover a wide variety of material, including consumer demographic and lifestyle information, market audits, and media audience size information (see 
Exhibit 9). Syndicated studies can provide data that is too expensive or difficult for individual organizations to obtain on their own.

The syndicated data industry focuses primarily on consumer packaged goods, but also includes some specific data sources for other industries. (See Exhibit 10 for some examples of these data sources.) This is a rapidly changing industry. Companies are expanding their services to new product lines all the time; new technologies are extending the breadth and depth of data available; and mergers and acquisitions are changing the major players (Schlossberg, 1990). The GreenBook (A ppendix A) includes information on companies offering syndicated data and cross-references them by services offered and product trademarks.

Exhibit 9. Examples of Syndicated Data Sources

\begin{tabular}{|c|c|c|}
\hline $\begin{array}{c}\text { Survey or Study } \\
\text { Name }\end{array}$ & Data Service Firm & Information Provided \\
\hline Product Volumes & $\begin{array}{l}\text { Mediamark Research } \\
\text { (New York, NY) }\end{array}$ & $\begin{array}{l}\text { Consumer usage behavior in relation to } \\
\text { many products and services, segmented } \\
\text { by demographics and usage. }\end{array}$ \\
\hline PRIZM & $\begin{array}{l}\text { Claritas } \\
\text { (Alexandria, VA) }\end{array}$ & $\begin{array}{l}\text { Consumer attitudes and behavior } \\
\text { towards many products and services, } \\
\text { segmented by geographics, } \\
\text { demographics, and lifestyle. }\end{array}$ \\
\hline Infoscan & $\begin{array}{l}\text { Information Resources, } \\
\text { Inc. } \\
\text { (Chicago, IL) }\end{array}$ & $\begin{array}{l}\text { Consumer purchase behavior integrated } \\
\text { with retail store audits, including sales } \\
\text { volumes, pricing, and promotional } \\
\text { activity; data is collected by scanning } \\
\text { product UPCs in supermarkets and other } \\
\text { retail stores. }\end{array}$ \\
\hline $\begin{array}{l}\text { National Television } \\
\text { Index }\end{array}$ & $\begin{array}{l}\text { A. C. Nielsen } \\
\text { (Northbrook, IL) }\end{array}$ & Television audience size. \\
\hline $\begin{array}{l}\text { Study of Media \& } \\
\text { Markets }\end{array}$ & $\begin{array}{l}\text { Simmons Market } \\
\text { Research Bureau (New } \\
\text { York, NY) }\end{array}$ & $\begin{array}{l}\text { Print media (newspaper and magazine) } \\
\text { audience size. }\end{array}$ \\
\hline $\begin{array}{l}\text { Broadcast Advertisers } \\
\text { Reports }\end{array}$ & $\begin{array}{l}\text { Arbitron (New York, } \\
\text { NY) }\end{array}$ & $\begin{array}{l}\text { Media audits, where television } \\
\text { programming is momitored. This } \\
\text { provides organizations with proof that } \\
\text { their advertising was shown. It also } \\
\text { provides information on competitors' } \\
\text { spending. }\end{array}$ \\
\hline
\end{tabular}


Source: Blankenship and Breen, 1993

Exhibit 10. Syndicated Data Sources for Different Industries

\begin{tabular}{|l|l|l|}
\hline \multicolumn{2}{|c|}{ Industry } & \multicolumn{1}{c|}{ Desearch Finn Service } \\
\hline Health and pharmaceutical & Pharmacentica Data Services & Hospital Data Services \\
\cline { 2 - 3 } & NPD Group & Healthpoll \\
\hline Automobile & J. D. Power and Associates & Power Early Buyer studies \\
\cline { 2 - 3 } & R L. Polk and Company & AutoMIS \\
\hline Computer & Audits \& Surveys & $\begin{array}{l}\text { National Computer Product } \\
\text { Audit }\end{array}$ \\
\hline
\end{tabular}

Source: Blankenship and Breen, 1993

\section{Q uestionnaires - The Primary M easurement Technique}

Questionnaires are the key measurement technique in consumer surveys. Features of a well-designed questionnaire include:

Questions that respondents can answer easily.

Questions that relate closely to the research project objectives.

- $\quad$ A tone and style that encourages respondents to cooperate (i.e., questions that are carefully styled to be respondent-friendly).

Questions that facilitate the type of data analysis required of the study.

Questions that are carefully sequenced and precisely worded to minimize bias and uncertainty. 
Types of Q uestions

Questions can be categorized by their function (i.e., special role) or their structural type (i.e., "closed-ended," or designed to have a limited number of answers, and "open-ended" for a broad range of answers). Exhibit 11 illustrates different types of questions, based on their function. Note that all of the examples provided are closed-ended questions.

Exhibit 11. Types of Questions Categorized by Function

\begin{tabular}{|l|l|}
\hline \multicolumn{1}{|c|}{ Function } & \multicolumn{1}{c|}{ Example } \\
\hline Qualifies respondent for study & Do you currently own a cellular phone? \\
\hline $\begin{array}{l}\text { Provides information on topic } \\
\text { under study }\end{array}$ & $\begin{array}{l}\text { How many times within the last week have you } \\
\text { used your cellular phone? }\end{array}$ \\
\hline $\begin{array}{l}\text { Allows classification by } \\
\text { demographics or other categories }\end{array}$ & $\begin{array}{l}\text { Which of the following income ranges include } \\
\text { your household income? (followed by several sets } \\
\text { of income ranges which have been defined as } \\
\text { relevant to this study) }\end{array}$ \\
\hline
\end{tabular}

While questionnaires generally make use of structured, closed-ended questions, they sometimes include unstructured, open-ended questions (Why do you prefer Product A over Product B?) when there are many possible answers or when the intent is to capture the respondent's own words.

Closed-ended questions are easier and less expensive to ask and to tabulate, with fewer chances for the interviewer to bias the results. Closed-ended questions also lend themselves readily to statistical analysis. (See Appendix B for examples of structured questions commonly used in marketing research.)

Information gathered through open-ended questions is generally of higher quality when followed by probes (What else did you like about Product $A$ ?) or clarifying questions (What exactly do you mean when you say Product B was difficult to use?). Probing and clarifying questions should not "lead" (i.e., suggest a response).

Length 
Obviously, questions must be direct and succinct. Telephone questionnaires must have even shorter, simpler questions than those administered in person or . by mail. 
Order

The order of questions in a questionnaire is anything but random. Once the respondents have been screened with qualifying questions, the questionnaire follows a well-defined course:

The first questions must be interesting, yet simple and nonthreatening -the intent being to involve respondents immediately and let them know that answering the questionnaire will be easy and enjoyable.

Questions proceed from the general to the specific, and from openended to closed-ended. It is best to ask reasons for product preference before asking a series of questions on product attributes. This prevents biasing or "educating" the respondent. Thus, the question "What considerations are important to you when purchasing a cellular phone?" should precede "How important is the telephone's size to you when purchasing a cellular phone?"

- $\quad$ "Sensitive" questions are best asked within a group of less difficult (or more innocuous) questions. The respondent is usually more inclined to answer in such circumstances.

Demographic questions (i.e., those relating to respondent's socioeconomic characteristics) are often the least engaging and sometimes the most sensitive questions. They should be positioned at the end of a questionnaire.

- $\quad$ Respondents are known to have a bias toward the first alternative on a multiple-choice question, when the question deals with concepts or ideas. To control this position bias, the order of items within a question should be rotated from one respondent to another.

W ording

Poorly worded questions can be a large source of uncorrectable error in a marketing research study. Questions must carefully avoid ambiguity. Preliminary testing of the questionnaire often brings to light those questions which are unclear. (See A ppendix C for some pointers on the wording of questions.) 
Preliminary Testing

A questionnaire should always have a preliminary test with a small number of participants, perhaps 15 to 30 people, similar to those who will participate in the actual study. This preliminary test can evaluate the wording of questions and the logic of their sequence, as well as the appropriateness of the data processing and analysis procedure. A preliminary test should be conducted at least once; if the questionnaire is complex and time permits, the process should be repeated.

Sample Design

Choosing the Right Sampling Frame

The sampling "frame" is simply a list from which the sample is taken.

Telephone books, city directories, and mailing lists are all sampling frames. It is usually easier and more efficient to obtain a list from an outside source than it is to generate it internally -unless the sample size is small, simple, or highly specialized.

Many of the same companies that sell syndicated consumer panel studies also deal in mailing lists and databases specifically designed for marketing research. R.L. Polk \& Co., for example, sells a list of over 78 million U.S. households, the "Polk X-I," which includes descriptive information about each household (Blankenship, 1993).

Sampling firms, such as Survey Sampling, Inc. (Fairfield, Connecticut), and M/ A/ R/ C (Dallas, Texas), offer extensive telephone sample lists and experts who specialize in sampling design. Sophisticated Data Research (Atlanta, Georgia) offers similar services for both consumer telephone and mail surveys. The GreenBook (Appendix A) carries a complete list of sampling firms, list providers, and sample design consultants.

Sampling Procedures

Sampling procedures -the ways researchers select their sample from a sampling frame-can be broadly classified as "nonprobability" and "probability" procedures. Nonprobability sampling procedures are not based on the laws of probability, but rather on the researcher's judgment. Three common types of nonprobability samples are:

Convenience samples -e.g., businesses use company employees as respondents in the early stages of product testing. 
Judgment samples -e.g., a technology or sporting equipment company uses "lead users" or experts to test exploratory or innovative products.

- Q uota samples -e.g., when the interviewer selects the first respondents who represent a population on previously defined characteristics, up to the proportion that these characteristics occur within the population.

Convenience and quota samples often are used for personal interviews because they are faster and less expensive than probability samples. Judgment samples can offer "expert" perspectives and insights that a cross section of the general public cannot provide (Herstatt and von Hippel, 1992).

While quota sampling and other nonprobability sampling procedures may not necessarily bias research results, it is not possible to measure the amount of this bias, nor is it possible to correct for it when analyzing the data. For these reasons, probability samples are generally considered more reliable and are used whenever possible.

In probability sampling, the chances of each member of the population being represented in the sample are known, because they are based on the laws of probability. The simplest type of probability sampling is random sampling with this method, each element of the population stands an equal chance of being selected. Typically, however, more complex sampling procedures are used.

A "proportionate stratified sample" is an example of one type of probability sample, resembling a quota sample in all ways except one: The sample members are randomly chosen within the strata.

Sample Size

Formulas exist that aid in estimating the statistically correct sample size for any confidence level (or probability) that the sample represents the population. However, sample size more often depends on how much time and money is available and how critical are the results. For quantitative studies, the customary minimums are:

Fifty respondents per category, if the sample is segmented or stratified.

- Two hundred respondents per variable. 
- Fifteen hundred respondents, if the sample represents the entire U.S.

Smaller samples are often used, especially in the exploratory stages of a project.

\section{Interviewing Methods}

Telephone interviews and personal interviews at shopping centers and malls (mall "intercepts") have replaced personal home interviews as the primary means of collecting survey data (Boyd,1989). Exhibit 12 rates these interview methods according to a number of different factors.

\section{Exhibit 12. Rating of Data Collection Methods on Different Factors}

\begin{tabular}{|l|l|l|l|l|}
\cline { 2 - 5 } \multicolumn{1}{c|}{} & \multicolumn{1}{c|}{ Telephone } & \multicolumn{1}{c|}{ Mail } & \multicolumn{1}{c|}{$\begin{array}{c}\text { Personal at } \\
\text { home }\end{array}$} & \multicolumn{1}{c|}{$\begin{array}{c}\text { Mall } \\
\text { intercept }\end{array}$} \\
\hline Quality of information & Excellent & Excellent & Good & Good \\
\hline Quantity of information & Limited & Limited & Excellent & Excellent \\
\hline Control of sample & Excellent & Poor & Good & Poor \\
\hline Sample response rate & Fair & Fair & Fair & Fair \\
\hline Supervision of fieldwork & Excellent & None & Fair & Good \\
\hline Time required & Fast & Slow & Slow & Moderate \\
\hline Cost & Low & Low & High & Medium \\
\hline Versatility & Fair & Fair & Excellent & Excellent \\
\hline
\end{tabular}

Source: Boyd, Westfall and Stasch, 1989

\section{Telephone Surveys}

Telephone surveys are often conducted from a central location, using computers for random-digit dialing (unlike the use of telephone directories, this method allows inclusion of unlisted numbers in a sample). Computers also prompt interviewers with questions on their monitors, and permit immediate entry of the information. This is called "computer-assisted telephone interviewing," or CATI.

Being fast and relatively cheap, telephone surveys are more common than any other mode of data collection. They are not without some attendant risks, however.

- Questionnaires must be highly structured, since this medium does not lend itself to probing. 
Interviewer bias is always a possibility. Quality of information is generally excellent, however, because cut-in listening allows a supervisor to monitor interviews.

Nonresponse bias may be high, since some respondents may regard an unsolicited telephone survey as an intrusion.

\section{M ail Surveys}

Like telephone surveys, mail surveys are easily administered from a central location. Unlike telephone surveys, however, mail surveys:

. Require at least two weeks to complete.

. Have no interviewer bias.

- $\quad$ Can be longer and more detailed (up to six pages).

. Can consist of a larger sample, since the cost per respondent is low.

- $\quad$ Can include visual material, such as print ads.

- Do not permit clarification of responses.

Because the interviewee does not interact with an interviewer, the mail survey is especially suitable when questions are highly sensitive in nature.

Despite the many advantages of mail surveys, they are successful only under certain conditions (Hague, 1990):

To achieve a high response rate, respondents must be strongly interested in the topic. A mail survey on new car purchases, for instance, will generate a greater response among the general population than a survey on gardening implements.

The topic must be clearly understood, to promote meaningful responses. A mail survey on improvements to an existing product will generate more meaningful information than one on new product ideas.

The mailing list must be carefully chosen, to avoid drawing conclusions based on the wrong population. 
- $\quad$ The questions must be straightforward, requiring no probing or lengthy responses. A mail survey with open-ended questions is unlikely to be returned with full responses.

Of these conditions, the first is the most influential: the higher the interest in the topic, the more valuable the response (Hague, 1990). Generally, the response rate should be greater than $15 \%$, but can be as high as $70 \%$ or more with a highly motivated sample (Blankenship, 1993).

Response rates can be increased in several ways:

A follow-up mailing two weeks later.

"Personalized" correspondence (e.g., use of a postagestamp not a metered stamp).

A relatively short questionnaire.

- Use of an incentive. But the risk in offering, say, a chance to win a trip to Hawaii, is that your responses are skewed toward those interested in a trip to Hawaii, rather than those with knowledge on the subject.

Personal Interviews

Personal interviews constitute the most versatile mode of data collection. They allow for lengthier, more complex, interactive sessions than do telephone or mail surveys. Personal interviews can include product demonstrations and visual presentations (e.g., video "loops" to engage the attention of passing shoppers).

Personal interviews remain the most expensive mode of data collection, however, and involve the greatest risk of interviewer bias, data falsification, and improper screening of respondents, particularly when interviewing entails fulfilling difficult quotas.

To minimize nonsampling errors, the research firm must be carefully chosen. Field audits must be made at the test site. Finally, questionnaires should include the respondents' telephone numbers to facilitate follow-up sample validation (Blankenship, 1993). 


\section{D ata Analysis}

D ata Tabulation

Data tabulation simply entails counting the number of cases that fall into various separate categories. Simple tabulation involves counting the responses to a single variable, such as brand preference. Results can be expressed as the percentage of respondents preferring each of the brands tested. Cross-tabulation involves setting up a matrix with two or more variables before counting the responses. This is the most common data-analysis technique in marketing research (Churchill, 1988) and is used to study relationships among variables and to gain insight into the nature of a relationship. For example, crosstabulation would be helpful in studying differences in brand preference by age category.

Often, data analysis ends with data tabulation. Other, more sophisticated techniques are sometimes used, however, to test for differences or for associations. Many of the advanced techniques are multivariate. Multivariate analysis takes into account the complexities of the marketplace through simultaneous analysis of two or more variables.

D ifference Tests

Difference tests apply statistics to cross-tabulated data and test hypotheses about samples. For instance, do men and women differ in how frequently they purchase a certain product? Or, put another way, is there a relationship between gender and frequency of purchase?

Some difference tests are designed for category data and some for numerical data. In either case, the confidence level is typically $95 \%$ by convention. The most cornmon difference tests are:

Chi-square goodness of fit-Compares the observed frequency with the expected frequency of an event. Chi-square is used on two or more categories or groups (e.g., consumers are segmented by lifestyle [categories] and surveyed on car ownership [the event]. Chi-square will determine if a statistically valid relationship exists between the two).

T-test-Compares the mean scores of two numerical ratings and determines if they differ significantly (e.g., two products are rated by consumers on a nine-point scale for overall acceptability. One product receives a mean score of 7.0; the other receives a 7.4. A Ttest will determine whether consumers actually found one product more acceptable than the other). 
A nalysis of variance -Compares the mean scores of three or more numerical ratings and determines if they differ significantly. This test is analogous to the T-test in all other ways.

A ssociation Tests

Factor analysis -A multivariate technique reducing a large number of variables or objects to a set of core, underlying factors. Factor analysis helps define key product attributes or market segments, and can be used to generate perceptual maps. Perceptual maps show how consumers divide the market, based on two or three primary factors. The position of each product on the market (or other category) becomes a point on the map. Points that are close to each other represent products that are perceived by the consumer to be most similar.

- $\quad$ Regression -Relates changes in one or several variables to changes in another (e.g., regression is useful in predicting how changes in product attributes will affect consumer receptivity).

- Multidimensional scaling --Examines relationships among various objects and is especially useful for determining consumer perceptions of similarities and differences among product brands or product categories, or for determining the combination of attributes yielding the ideal product. Multidimensional scaling can be used to generate perceptual maps.

- Conjoint analysis -Identifies the preferred combination of product characteristics or the trade-offs consumers make on such things as product attributes, price, and convenience. Conjoint analysis can identify how consumer attitudes interact, leading to buyer preferences and purchasing decisions.

Any of these techniques involving the formation of subgroups and segments bears with it a certain risk: The analyst can infer that a relationship exists within a group and that real differences exist among groups. These inferences may be proven incorrect by later research, which is why it is important to conduct a series of studies, rather than a single study, when identifying a particular relationship. 


\section{Marketing Research Limitations and Sources of Error}

\section{Limitations of Marketing Research}

Marketers often cite faulty marketing research as one of the most frequent causes of new product failure (Gruenwald, 1992). But this may not mean the research was done incorrectly. Often, the failure occurs when the manager is unaware of or ignores the limitations of the research. For example,

Conducting marketing research properly takes time and money. When either is in short supply, research may be seen as an obstacle; managers may take unwise shortcuts.

- $\quad$ Research alone cannot provide the "right" answer; managerial judgment and experience are needed.

Complexities of the marketplace are difficult to capture in research. Even with the most sophisticated techniques, such as simulated test markets, projecting market demand is an inexact science.

Complex forecasting models and multivariate analyses are not attractive, saleable items to managers seeking quick answers.

Surprise findings, especially in exploratory research, tend to be ignored in favor of expected findings.

- $\quad$ Consumers are unable to respond easily to unfamiliar products or services.

\section{Sources of Error}

Each step in the marketing research process can produce errors that introduce bias, inaccuracies, or uncertainty into a study (Exhibit 13). Many of these errors can be minimized, if not eliminated. Where errors cannot thus be dealt with, the researcher must know how these errors will bias the results.

Faulty marketing information, may also of course, be attributable to poorly planned or executed research.

Errors are generally categorized as sampling and nonsampling errors. Sampling errors occur because the whole population is not included in the study. For example, polls that predict voter sentiment before an election generally report a sampling error, or margin of error, along with poll results (Chandler, 1992). 
Because sampling errors are measurable and decrease with sample size, the bias they inflict on a study is at least known.

Although every study will have some degree of sampling error, the nonsampling errors are often the largest contributors to a study's total error. These errors occur at every stage in the process; because they are not easily quantified, they are more likely to be overlooked by researchers (Churchill, 1988). Since non-sampling errors become compounded as sample size increases, a carefully done study of 250 people can have a smaller total error than a study involving 2000 people. This is why a poll (or any marketing research study) reporting a small margin of error can still misrepresent the opinions of the population. 
Exhibit 13. Types of Errors in Marketing Research Projects

\begin{tabular}{|c|c|c|}
\hline Type of error & Definition/Source of error & Comments \\
\hline Sampling & $\begin{array}{l}\text { Limited sample size does } \\
\text { not allow true } \\
\text { representation of the } \\
\text { population. }\end{array}$ & $\begin{array}{l}\text { Measurable for a probability } \\
\text { sample. } \\
\text { Decreases with increasing sample } \\
\text { size. } \\
\text { Present in every study that is not } \\
\text { a census (where all population } \\
\text { members are included in the } \\
\text { study). }\end{array}$ \\
\hline Noncoverage & $\begin{array}{l}\text { Not surveying the "right" } \\
\text { respondents. }\end{array}$ & $\begin{array}{l}\text { Caused by a poorly defined } \\
\text { population, a poor sampling } \\
\text { frame, or the use of a } \\
\text { convenience or other } \\
\text { nomprobability procedure to } \\
\text { represent the general population. }\end{array}$ \\
\hline Nonresponse & $\begin{array}{l}\text { Respondents refuse to take } \\
\text { part in the study. }\end{array}$ & $\begin{array}{l}\text { Typically can be as high as } 40 \% \\
60 \% \text { for mail surveys. } \\
\text { Important to understand who is } \\
\text { not responding, how they may } \\
\text { differ from the respondents, and } \\
\text { if this biases the results. }\end{array}$ \\
\hline $\begin{array}{l}\text { Measurement } \\
\text { bias }\end{array}$ & $\begin{array}{l}\text { Order or wording of } \\
\text { questions creates } \\
\text { misunderstanding or biases. }\end{array}$ & $\begin{array}{l}\text { Can result in a very high } \\
\text { magnitude of uncorrectable error. } \\
\text { Minimized by pretesting the } \\
\text { questionnaire. }\end{array}$ \\
\hline Response bias & $\begin{array}{l}\text { Respondents fail to answer } \\
\text { questions truthfully or were } \\
\text { influenced by the } \\
\text { interviewer. }\end{array}$ & $\begin{array}{l}\text { Interviewer bias is especially } \\
\text { prevalent in exploratory research } \\
\text { or surveys with extensive } \\
\text { probing; bias minim\&d through } \\
\text { proper training and supervision } \\
\text { of personnel. }\end{array}$ \\
\hline $\begin{array}{l}\text { Recording, } \\
\text { coding } \\
\text { tabulating } \\
\text { or analyzing } \\
\text { errors }\end{array}$ & $\begin{array}{l}\text { Research staffmake } \\
\text { mechanical mistakes } \\
\text { recording and transcribing } \\
\text { data. The more complex } \\
\text { the research tool, the } \\
\text { greater the opportunity for } \\
\text { compound errors and } \\
\text { incorrect assumptions. }\end{array}$ & $\begin{array}{l}\text { Minimized through proper } \\
\text { training and supervision of } \\
\text { personnel and careful editing. } \\
\text { To minimize analysis errors, use } \\
\text { advanced techniques only when } \\
\text { absolutely necessary. }\end{array}$ \\
\hline
\end{tabular}




\section{Bringing New Products and Services to M arket}

\section{Overview}

There are many reasons for companies with successful products to look for ways to improve upon or branch out from their existing product line. Sales may be flat, competition may compel innovation, or someone within the company may have used existing core expertise to develop a new - and potentially profitable product prototype.

For the purposes of this report, a new product is different from an innovative product. A new product provides a variation in delivery, packaging, or content of an al ready recognized product or service. An innovative product defines a new market. For example the Boston Coach Company provides a new service reservable, private cars for hire - that is a variation on taxi cabs. The benefits travelers derive from such a transportation service are known to them through their personal experience with taxi service, but the venue of delivery provides new benefits of social elitism, cleanliness, comfort, safety, and reliability.

Telephone answering machines were an innovafive entry into the marketplace. Prior to answering machines, either there was a person present to answer a phone, or there was no way to get or leave a message. Initial market resistance to answering machines focused on how impersonal they were, on the personal insecurity of speaking into a machine and being recorded on tape, and on the possibility of the machine being undependable. However, in defining a broad social need which had previously been unrecognized, answering machines created a new market. Answering machines broke the time dimension of telephonic communication, changing the way people exchange information.

Many traditional approaches to marketing research, like those described in this report, are designed for modifications of existing products, and cannot measure or predict the consumer's response to innovative products. It was for this reason that marketing research erroneously predicted the failure of the movie Star Wars (Ward and Reibstein, 1979) and the Xerox copier (Hague, 1990).

Section 5 presents a framework of market research activities which companies pursue in the exploration of a potential product. This series of progressively more detailed stages of inquiry is similar for both new product and innovative product research, with market research activities for innovative products encountering different considerations at each step. Section 6 will address the specific differences that occur when introducing an innovative product to the market. 


\section{Marketing Research Steps in the Introduction of a New Product}

A typical sequence of marketing research steps in introducing a new product is depicted in Exhibit 14. Each of these steps will be described in the following pages. The order in which these steps are pursued vary depending on type of company and type of product. In theory, each stage in the series of market research activities is successive, with the inquiry at the first stage leading to a better definition of the inquiry at the next stage. However, in practice these stages overlap, are at times pursued simultaneously, and often inform the previous stage.

Exhibit 14: Marketing Research Steps in the Introduction of a New Product

\begin{tabular}{|c|c|}
\hline Step 1 & Product Development \\
\hline Step 2 & Market Analysis \\
\hline Step 3 & Concept Testing \\
\hline Step 4 & Market Segmentation \\
\hline Step 5 & Product, Pricing, and Advertising Testing \\
\hline Step 6 & Sales Forecasting \\
\hline Step 7 & Product Introduction \\
\hline Step 8 & $\begin{array}{c}\text { Post-Introduction Product Performance } \\
\text { Monitoring }\end{array}$ \\
\hline
\end{tabular}

\section{Step 1. Product D evelopment}

Ideas for new products come from various sources. Often, a company will fund exploratory research to find ways to improve upon or branch out from their existing product line. Another source is consumers who provide ideas for product improvements, or define a new product that is needed. One way to get this information is to monitor consumer complaints on current product 
performance (Boyd, 1990). Focus groups are another way. Such groups are ideal because ideas are bounced around among the group members and can be developedfar more than is possible in one-on-one interviews (Hague, 1990).

\section{Step 2. Market A nalysis}

Market analysis consists of gathering data, often through secondary research, to better understand the economic, market and competitive environment. The primary objective is to arrive at an early, but realistic, projection of sales of a product. Market analysis helps a company better understand:

- $\quad$ The economic environment, including potential competitors and their offerings.

Initial product positioning, which includes defining what will differentiate the tested product from its substitutes.

Obstacles to the product's use, such as a need to purchase some form of insurance before the product, for instance a car, can be used.

Whether there are likely to be any geographic or regional variations which will affect demand.

Market analysis is also used to identify the market niche the company expects to occupy. It requires a thorough identification of potential competitors and what niche competitors' products occupy on the market. Sources for market analysis include SIC (or industry) codes, industry profiles, industrial market data, and product classification by physical (or other relevant) characteristics and benefits.

D efining $M$ arkets

The first task in conducting a market analysis is identifying the various markets in which the product has opportunities. A traditional way to do this is to classify the market by a product's physical characteristics. For example, traditionally, auto manufacturers have divided the market into subcompact, compact, mid-size, full-size, and luxury autos. Other ways exist, too, but the best way is based on how consumers perceive the relative similarity of product benefits and features.

Evaluating $M$ arket Pofeniial

Once markets for a product or service are defined, the attractiveness of entering these markets can be evaluated. Urban and Hauser (1980) list six general factors to consider in evaluating market potential (Exhibit 15). They recommend that these be enumerated and weighted by the organization for relative importance, then used to rate each defined market. The markets with the highest ratings represent the best opportunities. 
Exhibit 15. Factors to Consider in Evaluating Market Potential

\begin{tabular}{|l|l|}
\hline \multicolumn{1}{|c|}{ Factor } & \multicolumn{1}{c|}{ Measure } \\
\hline Sales Potential & $\begin{array}{l}\text { Size of Market } \\
\text { Sales Growth Rate }\end{array}$ \\
\hline Penetration & Vulnerability of Competitors \\
\hline Scale & $\begin{array}{l}\text { Share of Market } \\
\text { Cumulative Sales Volume }\end{array}$ \\
\hline Input & Investment in Dollars and Technology \\
\hline Reward & Profits \\
\hline Risk & $\begin{array}{l}\text { Stability } \\
\text { Probability of Losses }\end{array}$ \\
\hline
\end{tabular}

\section{Step 3. Concept Testing}

Concept testing measures the appeal of a product idea to consumers by drawing upon embedded company knowledge and experience, frequently in conjunction with interviews and focus groups. It is used to formulate a hypothesis about the product's benefits and features, and about the segments of the general population which will comprise the primary target market. Concept testing is product- and benefit-oriented and uses the following market research tools:

- $\quad$ Focus groups.

. $\quad$ "Expert" interviews.

- $\quad$ Product prototypes.

For instance, a typical concept test for a new packaged good is a consumer survey, often conducted in a mall, as follows:

- $\quad$ Consumers are screened as qualified respondents.

- Consumers are shown a "concept board" (a product or service description, accompanied by a drawing or photograph). This can be in the form of a draft advertisement.

They are asked a set of questions:

purchase intent?

likely purchase frequency? 
a series of diagnostic questions on why they would purchase the product, or why they wouldn't.

Based on consumer response to these questions, a computer model estimates product trial rates. The consumer packaged goods model is based on norms developed over the years by research firms tracking purchase intent data with actual product trial rates.

When concept testing does not accurately predict consumer response, it is for one of three reasons:

- $\quad$ Concept testing cannot easily predict repeat buying. Items that test well at the concept stage may have a high initial trial, but can turn out to be novelties.

- $\quad$ Such testing cannot get at how well the actual product will deliver against the concept. A concept can test well and a product can test well, but unless the product is tested with the concept, it is difficult to know if the consumers who are attracted to the concept will have their needs met by the product.

- $\quad$ Concept testing is only as good as the norm it is based on. Many consumer packaged goods have well-established norms; other product classes, such as consumer durables, do not. hnovative products tend to test poorly at the concept stage (Blankenship, 1993).

A new concept test for consumer durables is the Information A ccelerator (Hauser, Urban, and Weinberg, 1992). The Information Accelerator is conducted using a multimedia computer that simulates the buying process. Depicted are product advertisements, interviews with consumers, magazine articles, and a car showroom. The respondents choose which items they wish to view and for how long. They are then asked purchase intent. Long-term tracking is needed to link these purchase intent responses to purchase probability.

Market analysis and concept testing are often done concurrently. Together, they support the formation of a preliminary hypothesis about product benefits, consumer response, and level of demand for the product on the market. They create an outline of the needs and motivations of the potential consumer, which then supports the product and market development process. The product/ market hypothesis is then tested and refined against the following, more conclusive forms of market research in order to produce a plan for product introduction and support. 


\section{Step 4. M arket Segmentation}

Market segmentation divides consumers into distinct groups, or segments, of consumers with similar needs and characteristics (Boyd, 1989). Well-defined segments are easier to target with specific products and market strategies. This stage of research depends heavily upon interrogative research methods of all types. Gathering more conclusive lifestyle and demographic information on the potential consumer allows the company to develop greater depth of knowledge about the targeted market and consumer. Most important, more detailed market and consumer information helps the company identify who the early and secondary product buyers are likely to be. Consumer information can be gamed from census data, proprietary secondary sources and reports on consumer trends (such as the Popcorn report), followed by surveys and focus groups.

There are four major ways of defining segments:

- $\quad$ Customer needs - e.g., prestige or convenience.

- $\quad$ Product-related behavior - e.g., brand loyalty and frequency of product use.

General behavioral descriptors - e.g., lifestyle or personality traits, including the propensity to adopt innovative products.

- Demographics - e.g., age, gender, ethnic origin, and income.

To increase market demand for existing products, a typical use of market segmentation studies might be: to segment customers on the basis of one or more product-related behavioral variables; conduct focus groups and surveys on each of the segments, looking for differences in benefits sought, demographics, and lifestyle; and thereafter develop a product line extension or create advertising targeted for one or more specific segments.

In identifying new products or opportunities, the process may be modified to segment customers on the basis of needs or ben efits; conduct focus groups and surveys to identify segments whose needs are not satisfied with current offerings, or who could benefit the greatest by new offerings; further segment those groups by general behavioral and demographic descriptors; and finally, design a product and marketing strategy targeted for identified segments.

Because of the expense involved in segmentation studies, it is often more costeffective to use syndicated services to obtain this type of information. 


\section{Step 5. Product, Pricing, and Advertising Testing}

Commonly the components of a product and its marketing strategy are tested, including pricing, advertising, and promotion. Once these components are individually tested, risk is further reduced by testing the integrated package.

A company that learned the hard way that testing product performance alone can be risky is Coca-Cola. In 1985, Coca-Cola introduced its sweeter, "improved" version of Coke. The company described as "overwhelming" the results of taste tests with 190,000 consumers, the majority of whom preferred the new formula over the old Coke (Alsop, 1985). Yet the introduction caused a revolt among loyal fans of the 99-year-old soft drink. The taste tests, it was later reveal ed, were conducted blind, with the brand name and product concepts undisclosed. By using this test design, the company failed to consider the impact of the formula change on Coke's image as "classic". A final market research test on the product with its brand name and concept would have been a less costly way to go.

\section{Product Testing}

Product testing allows a company to better understand product performance and features. It defines who uses the product, how they use the product, when/ where they use the product, as well as the actual performance and functionality of the product in "normal" use. Product testing includes:

- $\quad$ The use of simulated products or prototypes in order to give consumers experience with and understanding of the products and its benefits.

- $\quad$ Surveys.

- $\quad$ Focus groups.

- $\quad$ Logs (both computerized and manual) used for the measurement of benefits, such as the amount of time saved by the use of the product.

Surveys and controlled experiments are frequently used in product testing. The task is relatively simple when the physical characteristics that are important to consumers are limited and known. Consumers use scales to rate products on these characteristics and on overall acceptability; difference tests are used to determine if products differ.

When testing new products, the physical characteristics important to consumers may not yet be known. One conceptually simple way to identify the most preferred combination of characteristics is to test all combinations and see which is most preferred. A more realistic process is to design a controlled experiment in which only a fraction of the feasible products are considered (Urban and 
Hauser, 1980). This is called a "fractional factorial" experiment. A fractional factorial experiment can be combined with a multivariate analytical technique, such as conjoint analysis or multidimensional scaling, to identify the ideal product. This can be done with product descriptions when actual products are unavailable.

Through the use of product prototypes, surveys and focus groups, product testing allows the company to generate data on consumers' perceptions, including:

- Information regarding the most acceptable models of payment.

- What price points correlate to which bundle of services.

- Which product features are most valuable.

- Whether any feature designs require adjustment.

Whether other issues will crop up with product introduction, for example, increased or decreased insurance rates or specific repair needs and servicing.

Product testing may also uncover additional applications of the product that were unrecognized at the point of concept generation. Product testing is particularly critical when testing an as yet unknown product, for it helps provide insight into how to stimulate market demand when that demand is latent or unconscious. Much of the market demand and consumer research conducted within the operational tests falls into the product category of market research.

\section{Price Testing}

The "right" selling price for a product under one set of market conditions may be the wrong price under another. Precise estimates of consumer sensitivity to prices are either impractical or unreliable; directly questioning consumers may not get at actual purchase behavior. Often, pricing decisions are made intuitively or by studying the buying behavior and decision processes of consumers, nof by directly asking the consumer about pricing.

Nagle (1987) discusses nine general effects that influence consumer price sensitivities, including the unique value effect and the price/quality effect. Focus groups and surveys that address these effects can provide information to supplement managerial judgment in making pricing decisions.

When complex interactions among factors and a high degree of uncertainty exist, formal controlled experiments may be worth the time and money. Conjoint analysis has become popular for measuring price sensitivity - its strength being its ability to disaggregate a product's price into the values consumers attach to each attribute (Nagle, 1987). This way, organizations can design new products that include only those attributes that consumers are willing to pay for. 
Yankelovich, Clancy, \& Shulman is one marketing research company that provides trade-off analysis, a type of conjoint analysis, as a service.

Advertising Testing

Marketing research is used in developing advertising copy and in evaluating its effectiveness. A good example of how marketing research can help develop advertising copy is provided by DDB Needham Worldwide, the advertising agency for Southwestern Bell Mobile Systems (Winski, 1990): Southwestern Bell had the following demographics information on its cellular telephone market in the Dallas-Fort Worth area:

Males, 25-54.

- Income greater than $\$ 35,000$.

- $\quad$ Time spent weekly in their cars on business or commuting: 1 to 7 hours.

DDB Needham Worldwide matched behavior and values characteristics from its Life Style Study to this demographics information; found that targeted individuals exhibited the following characteristics; and developed an advertising campaign specifically designed around this information:

- $\quad$ Self-confident and ambitious.

- $\quad$ Outgoing and physically active.

. $\quad$ Valued their time and considered themselves trendsetters.

. $\quad$ Enjoyed influencing business associates and friends.

Advertising effectiveness is measured to determine an ad's impact on the target audience. It is most often measured for television, rarely for radio or print. Several major services are available that provide clients with measures of information awareness, memory (information retention), and persuasion.

\section{Step 6. Sales Forecasting}

Several methods are available for predicting sales volumes of a product prior to national introduction; laboratory and field research experiments play a large role. Although expensive compared with exploratory or descriptive research, controlled experiments can provide sales forecast estimates and diagnostic information for improving market performance in as little as ten weeks.

Testing can take several forms:

- $\quad$ Simulated test markets - Laboratory experiments traditionally used to test consumer packaged goods. More recently, modified versions have been used with consumer durables and services (Clancy and Shulman, 1992). 
Input includes the physical product, advertising copy, packaging, and pricing, and the advertising and promotion budget. The output is a forecast of sales based on trial and repeat purchase measurements and diagnostics (Urban and Hauser, 1980). The actual test involves giving consumers information about a test product, generally in the form of advertising. They are then provided with funds and given an opportunity to purchase the product in a mock store. Following product use, the participants are interviewed to determine the likelihood of repeat buying and buying frequency. Finally, based on this data, a computer model provides an estimate of sales volume.

Consumer test clinics - A nother type of laboratory experiment, most often used to test consumer durables (Urban, Hauser, and Roberts, 1990). In a test clinic, a product mock-up is used, since many consumer durables, such as automobiles, are unavailable in final form before full-scale production.

Controlled test markets - Field experiments on consumer packaged goods that provide direct control over product distribution, pricing, advertising, and promotion. Information Resources, Inc. provides this service under the trademarked name "Behaviorscan".

- $\quad$ Full-scale test markets - Field experiments commonly used for consumer packaged goods and for services. These experiments are run under normal market conditions, in cities that represent, as closely as possible, the national market.

A ppendix D compares a simulated test market to a full-scale one. Simulated test markets are conducted by companies that use proprietary simulation models and syndicate their services. The leading companies include:

Bases (Burke Marketing Research, Cincinnati). Macro Assessor (M/ A/R/ C, Irving, TX).

Litmus (Yankelovich, Clancy, and Shulman, Newton, MA).

\section{Step 7. Product Introduction}

The outcome of these stages of research is a market and product introduction plan that provides increasingly detailed information about product roll-out, market development, and product support.

\section{Step 8. Product Performance Monitoring}

Product performance monitoring begins at the time of product introduction and is designed to monitor market response to the product; this activity becomes intertwined with ongoing product development and market development activities. 


\section{Bringing Innovative Products and Services to Market}

\section{Overview}

Many traditional approaches to marketing research, like those described in this report, are designed for modifications of existing products, and cannot reliably measure or predict consumers' response to innovative products. The core of the difficulty in measuring consumer response to an innovative product is the consumer's lack of personal experience with the product. This is especially true of IVHS products and services. This final section of the marketing research primer will summarize some of the major challenges facing marketing research when the product is innovative.

\section{Definition}

Innovative products create a shift in the way a consumer functions. Using the innovative product provides the consumer with solutions to problems or needs that were previously unmet or unrecognized (also referred to as latent). As shown in the example in Section 5, Boston Coach simply replaced other forrns of transportation; answering machines have shifted the manner in which we exchange information and consequently has altered our lifestyles.

\section{Marketing Research Challenges}

The challenge of measuring market demand for innovative products can be attributed to the differences in the innovative product's origin (or how and where it was developed), lack of consumer experience with a similar product, lack of company experience with the product, and the market risks.

\section{- $\quad$ Product Development/ Origin:}

Innovative products are often the result of a technology breakthrough, rather than an outcome of consumer and market monitoring. Its applications and benefits, and thus its final form, are not fully defined until after several iterations of market research have been completed. An innovative product may require consumer research with a series of formative prototypes before the product is ready for market release.

An innovative consumer product may have its origin in the commercial or industrial sector. This was true for the Cuisinart food processor. While the commercial food industry had experience with the benefits of electric food processors, it was unknown in the consumer market. Gaining an accurate assessment of how the consumer market would respond to the 
Cuisinart was difficult because of the following "innovative" product characteristics: the food processor required a shift in the behavior of the home cook, it had not yet established any distinctive value to the home cook, and it was much more expensive than existing electric kitchen utensils, such as blenders.

- Consumer Response:

Consumers have had no direct experience with the innovative product.

Consumers do not respond reliably to tests of products (or product concepts) with which they have had little or no previous experience; they find it hard to envision where such a product would fit into their lives. This is especially true of those products where usage requires a shift in the consumer's lifestyle or routine. Product prototypes may be provided for consumers who participate in the marketing research program so that they can learn to use and apply the innovative product in context prior to providing feedback to the researchers.

\section{Company Experience:}

The company has had little experience marketing, selling, or supporting the product. The company has less collective, embedded understanding of the innovative product's market and no established expertise in managing the product. As a result, more marketing research must be devoted to determining product position, market channels, sales support, pricing, warranty, and post-introduction product support; and more research will follow product release to monitor market response.

- $\quad$ Market Risks:

The market holds special hazards for innovative products. Bringing an innovative product to market is a costly process, requiring more research, longer research, and more advertising. The first innovative product to enter the market defines the new market, and brings potentially great reward. But, if the company hasn't sufficient lead time ahead of its competitors, it may lose the financial advantage that first-to-market claims. Thus, despite the need for a longer market research program to define innovative products, there is pressure to bring the product to market as soon as possible.

\section{Research Approach}

The problems that an innovative product introduction creates affects every component of market research, and causes the research program to proceed more slowly, at greater expense, and with more iterative exchange between steps 
in the process as compared with new products. The four conditions described above influence both the order of the market research inquiry and the content of each stage. Generally, the course of the research program on innovative products is less predictable.

In the approach of a research program to the innovative product, the steps which have been outlined in chapter 5 may merge and be pursued concurrently. For instance, after developing an idea for an innovative product, the first step might be to simultaneously prototype the product and identify a preliminary set of benefits and applications. The preliminary set of benefits then would be used to identify expert users in related fields who would be called upon to test the product (or concept) and provide a better idea of how the product's functions or applications would benefit them. With this preliminary expert user input, the product (or concept) would return to $R \& D$ for refinement, while at the same time market researchers would begin a market analysis, identifying potential market positions and competitors. The product may repeatedly return to $R \& D$ for refinements while market research continues on with more definitive and conclusive research.

The following sections highlight some of the exceptional features of marketing research done in appraisal of an innovative product or service.

Product D evelopment

As discussed earlier, the innovative product may emerge as a result of a breakthrough in function, format, application, or production, and it is sufficiently new to the consumer market to be without obvious and known consumer benefits. Because the product emerges from product development without a consumer history, the marketing researchers and product engineers together must adopt a more experimental approach to the process of. refining the product and bringing it to market.

$M$ arkef A nalysis

A market analysis requires some knowledge of the proposed product's expected benefits and features. At this point in the innovative product's development cycle, there is only a preliminary hypothesis describing the product's future market possibilities. A market analysis performed at this stage in the product development cycle may take the form of a case study that analyses the product's expected benefits in relation to those segments of the consumer population who are considered likely to value these benefits.

Market analysis may proceed apace with concept testing or follow it. The objective of the market analysis is to qualify the product for further development and to refine the market hypothesis. 
Once the innovative product (or concept) has emerged from $R \& D$, the first objective of market research is to answer some preliminary questions about the proposed product and its potential applications. In testing an innovative product, the first questions are:

(1) What is the likely function/ application of this product?

(2) What are the apparent benefits of using this product?

(3) What are the characteristics of the consumers who will first and foremost benefit from use of this product? And, who among them are the "expert" users?

With an innovative product, concept testing is more likely to depend upon focus groups and expert users, and may require use of a product prototype which can be tested in context. Commonly, the prototype is provided first to company employees to test in the context of their own lives and, through an informal focus group, provide feedback on functionality, features, and benefits. Then, the prototype will be distributed to "expert users" from outside of the company, possibly well known clients or customers, to similarly incorporate in context and provide feedback.

M arket Segmentation

For innovative products, market segmentation based on demographics and previous buying habits is less important than defining, locating, and understanding the lead users. Lead users are those customers who make the most advanced use of new technology and products (Kotler, 1991), and tend to have more advanced needs from the product quite some time before other, average users do. Lead users make up between $2 / / 2$ - 4\% of any market and are not hesitant to spend money on the latest product or improvement. They are an important source of education and promotion to other consumers.

\section{Product, Pricing, and Advertising Testing}

The predictive capability of product, pricing, and advertising testing of an innovative product is enhanced by the use of a prototype. A prototype is especially useful when the functionality or performance of the product is complex, to assess the consumer's ability to use the product, and to identify the "bugs" which emerge through more regular and unsupervised use. However, it is costly to develop a fully functional prototype, and the prototype's idiosyncratic characteristics may bias consumer response. Creating a prototype may also act as an inadvertent release of information to a competitor. 
Products which are complex and "expensive" relative to existing substitutes, such as in-vehicle route guidance and navigation products, are likely to require a very long product testing period. For example, one such product entering the market now has been in progressively more conclusive product testing for over two years. Even though it would appear to be "on the market" now, the company is more probably using the "market release" as a geographically defined full-scale market test to test various aspects of the marketing mix and to determine a competitive and profitable price point.

Products which are complex may require mastery of instructions before the consumer is able to realize the full benefit of the product. The longer and more challenging the learning period relative to the value attained, the more difficult the product will be to sell. Consider the evolution of the automobile: in the decades since the auto's introduction, it has become increasingly easy to operate a car, and the benefits which cars provide have increased in the value.

Automatic transmissions, power steering and brakes opened a large new market to driving. Similarly, consider the evolution of the personal computer market: early PCs required consumers to learn programming languages; as the product became easier to use, the value of the PCs benefits increased and the market grew. Product testing helps to determine how best to instruct the targeted user group in product operation, and may help to identify product protocols which can be streamlined or eliminated so as to make the product more accessible to general consumer use.

Without proper and properly placed advertising, innovative products may not sell. Consumers may not recognize the product's performance capabilities and they may not be aware that they have need for the benefits an innovative product promises to deliver. Advertising informs potential consumers that they have a need (heretofore unrecognized) that the innovative product can meet. Advertising testing enables the company to determine how much education the advertising campaign will need to accomplish to arouse in consumers a recognition of need or benefit.

Where an innovative market is expected to be very competitive and very profitable, as with personal digital assistants, a company may develop and initiate its advertising campaign before the product has been developed. In this example, the benefits and beneficiaries of PDAs were defined and pursued by Apple Computer as a preemptive strategy to prevent competitors from capturing the innovative market, and to enhance the company's image as "leading edge". The company gambled that it would develop a product that defined and exceeded the needs of the market, thus shutting out its competition for a period of time. The risks with this approach include promising more than the product is able to deliver, thus ultimately depressing demand, and exposing corporate strategy to competitors, thus risking the possibility that another company will be first to market and capture the benefits of the investment in market development. 
Sales Forecasting/ Predicting Product Diffusion

Identification and monitoring of lead users is central to forecasting sales. How quickly lead users adopt the innovative product is often a good prediction of how fast the product might "diffuse" or penetrate the rest of the market. Diffusion, as defined by E.M. Rogers is "the spread of a new idea [or product] from its source of invention or creation to its ultimate users or adopters." (Rogers, 1962). Rogers is credited with the development of diffusion theory; through his work he has demonstrated that diffusion theory applies to new, innovative products, not to variations of existing products (Shanklin and Ryan, 1987). Rogers proposed that the rate of diffusion of an innovative product is dependent upon five factors:

Relative Advantage

Compatibility

Complexity

Divisibility

Communicability
The extent to which the innovation is perceived as superior to the current offering.

The extent to which an innovation fits with existing consumer expectations, habits, and lifestyles.

The perception of how difficult the innovation is to understand and use.

The size of the smallest meaningful or obtainable unit of the innovation; a measure of the financial risk inherent in adopting the innovation.

How easily the features and benefits of an innovation can be observed and described to nonusers.

For purposes of market analysis, Shanklin and Ryan have developed a model of the diffusion process that provides two important pieces of 'information. It classifies consumers by their buying behavior and it models the rate at which innovative products diffuse through the market:

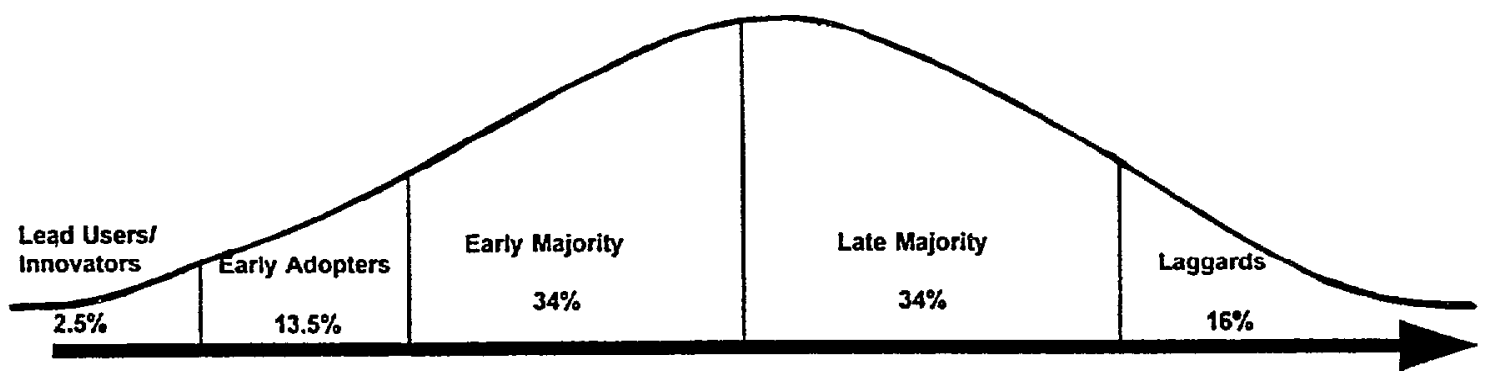

TIME 
This diffusion model helps companies predict significant differences in the buying patterns of different market segments. The targeting of lead users is an important starting point for successful innovative product introduction; how quickly this segment adopts the innovative product is predictive of how quickly the product will move through the following segments.

\section{Product Introduction/P ost-Introduction M onitoring}

Market response to an innovative product's introduction is more uncertain than for a new product. Despite the best research results, products fail. Remember New Coke, Beta, and large cassette tapes. Also the product's performance is uncertain because the product is being manufactured (versus crafted) for the first time. These circumstances require the company to closely monitor the product's performance and the consumers' response. Purchase and return rates, advertisement response, wholesalers' and retailers' feedback, are all monitored to ascertain whether market response is as predicted and for the reasons predicted.

Some innovative products are released onto the market incrementally, accompanied by continued product and market testing, such that there is no clear distinction between pre-release market research and post-introduction market monitoring. This highlights an important feature of the innovative market research/ market release continuum: the research never stops. As described earlier regarding the navigation guidance product, what appears to the public to be a product introduction, may in fact be another stage in the continuing marketing research program. The company will continue to convene focus groups and surveys of both consumers and salespeople to monitor waves of response (referring back to the diffusion model) and product applications. Over time, the research focus changes as the product becomes more securely established on the market. 


\section{Sum mary}

Marketing research is undertaken in the private sector to limit the risk attendant upon introducing new products to the market, and to discover unmet needs in the market which can be met through developing new products (or product benefits) and services. The depth and duration of the research is usually a function of the amount of risk, determined by the cost of new product development and support, the amount of potential profit, and the degree of market uncertainty. The approach taken in assessing the market for a new product generally includes an analysis of the benefits provided by existing products; an analysis of competitors, socioeconomic, and environmental factors; and, an assessment of the needs (latent and expressed) of potential consumers. This primer has focused on the methods and tools which are applied to consumer research, as those are the methods relevant to measuring consumer response to and demand for ATIS products and services.

Marketing researchers approach the research program with a hypothesis describing the product's benefits and the types of people who are most likely to find the product's benefits compelling. Research generally begins with qualitative exploratory inquiries, like focus groups, to further develop the product/ consumer hypothesis. Once the product benefits and consumer segments become more clearly defined, more conclusive quantitative research is pursued, such as surveys and controlled market experiments. Through successive iterations of increasingly more conclusive and specific forms of research, including advertising and price testing, the product is prepared for market release.

Depending upon the potential size of the targeted market and/ or the complexity of the product, the product release may be limited, with the initial release targeting defined sub-markets, such as small, mid-western cities. In such cases, the submarket defines a representative proxy of the target market, much the way consumer segments define an entire population. These controlled product releases are known as a full scale market tests and they are part of an extended marketing research program that enables researchers to test their conclusions against a true market, with all its attendant complexities. Following product release, marketing research will continue with point-of-sale data and other research that tracks product acceptance rates and validates assumptions regarding product uptake, performance, and support requirements.

Consumer research methods are based upon established standards for probability and statistical reliability, and are used to accurately isolate and examine the preferences of a representative subset of the targeted population. The information gathered from the subset is then generalized to the larger 
population as a basis for predicting the size and behavior of the market. Interrogative methods generally rely on consumers stated preferences and include both qualitative and quantitative techniques; controlled and full-scale test markets provide revealed preference data. Sophisticated research designs and data analysis techniques, largely based on prior experience with similar products and markets, enable researchers to predict the future life-cycle of new products.

Marketing research can also fail. The complexities of market and consumer behavior are difficult to capture with research. There are as many reasons for faulty predictions as there are failed products, but several causes are worthy of note. Within the research program itself, common errors can be categorized as: sampling; non-coverage; non-response; measurement bias; response bias; and recording, coding, tabulating or analyzing errors. Other problems include:

- $\quad$ The product manager may not understand or properly apply the findings of the marketing research.

- $\quad$ Surprise findings tend to be ignored in favor of expected findings.

Consumers are unable to respond reliably to unfamiliar, or innovative, products and services.

Innovative products, like many of those included in IVHS, pose special challenges to marketing research. The core of the difficulty in predicting market response to an innovative product is the consumers' lack of personal experience with the product or service. Other challenges include the product's origin, the company's inexperience with the product, and the inherently higher risks associated with bringing an innovative product to market. As a result, the research program proceeds more slowly, at greater expense, and with more iterative exchange among the steps within the research program. The following points are representative of what distinguishes research on innovative products from traditional research on existing products or product line extensions:

A judgement sample of lead users often provides better insight than a probability sample of the general population.

The questions asked of potential consumers in product surveys and focus groups are best phrased in terms of product benefits, rather than product attributes.

- While the use of a product prototype is frequently required, prototyped devices have idiosyncratic characteristics that can bias consumer response.

- $\quad$ Early attitudes may not predict consumer behavior; attitudes may change as the consumer gets more experience with the product. 
Marketing research attempts to model the uncertainty of human behavior in complex systems. When properly applied, the procedures and tools utilized in this effort are remarkably reliable predictors of human and market response. However, even the most sophisticated of these tools are based - in part - upon observed past behavior. This, combined with the many other risks attendant upon a major research program, explains the difficulties of accurately predicting consumer response to innovative products. 


\section{Bibliography}

Adler, Lee (1979), "Secrets of when, and when not, to embark on a marketing research project", Sales and M arketing M anagemenf, 123 (Sept. 17), p. 108.

Adler, Lee (1980), "Secrets of when, and when not, to embark on a marketing research project", Sales and M arketing M anagement, 124 (March 17), p. 108, (May 19), p. 77.

Alsop, Ronald (1985), “Coke's Flip-Flop Underscores Risks of Consumer Taste Tests", Wall Street Journal, July 18, p. 27.

Anonymous (1984), "How IBM Made 'Junior' an Underachiever", Business W eek, June 25, pp. 106-107.

Blankenship, Albert B. and George E. Breen (1993), State-of-the-Art M arketing Research, Chicago, IL: NTC Business Books.

Boyd, Harper W. and Orville C. Walker (1990), M arketing M anagement, Homewood, IL: Richard D. Irwin, Inc.

Boyd, Harper W., Ralph Westfall, and Stanley Stasch (1989) M arketing Research: Text and Cases, Homewood, IL: Richard D. Irwin.

Chandler, David L. (1992), "Polling: Methods Behind the Madness", Bosfon Globe, November 2, p. 48.

Churchill, Gilbert A. (1988), Basic M arketing Research, Orlando, FL: The Dryden Press.

Clancy, Kevin and Robert Shulman (1992), "It's Better to Fly a N ew Product Simulator than Crash the Real Thing", Planning Review, 20 (4): 10-17.

Duke, Robert (1990), "Success and Failure in Marketing Innovation: Videotape vs. Laservision", M anagement D ecision, 28(7): 5-190.

Friar, John H. (1993), “Targeting Initial Customers and Applications for Emerging Technologies", Working Paper, Boston, MA: Northeastern University.

Gruenwald, George (1992), N ew Product D evelopment: Responding to M arket D emand, Chicago, IL: NTC Business Books. 
Hague, Paul (1990), "Using Mail Response to Test the Water for New Products" Business M arketing Digest, 15 (2): 61-70.

Herstatt, Cornelius and Eric von Hippel (1992), “From Experience: Developing New Product Concepts Via the Lead User Method: A Case Study in a 'Low Tech' Field", Journal of Product Innovation M anagement, 9(3): 213-221.

Kinnear, Thomas C. and James R. Taylor (1991), M arketing Research: An A pplied A pproach, New York, NY: McGraw-Hill, Inc.

Kotler, Philip (1991), M arketing M anagement: A nalysis, Planning, Implementation, \& Control, Inglewood Cliffs, NJ: Prentice Hall.

Mitchell, Russell (1986), "How Ford Hit the Bull's Eye with Taurus", Business W eek, June 30, pp. 69-70.

Nagle,Thomas T. (1987), The Strategy and Tactics of Pricing, Englewood Cliffs, NJ: Prentice-Hall, Inc.

Pope, Jeffrey L. (1981), Practical M arketing Research, New York, NY: AMACOM.

Rogers, E. M. (1962), Diffusion of Innovations, New York, NY: Macmillan.

Schlossberg, Howard (1990), "Simulated vs. Traditional Test Marketing: The First One's Improving, The Other is Hardly Dead.", M arketing N ews, Oct. 23, 1989, pp.I-2, 11.

Shanklin, William and John K. Ryans, Jr. (1987), Essentials of M arketing High Technology, Lexington, MA: D.C. Heath and Company.

Urban, Glen L. and John R. Hauser (1980), D esign and M arketing of N ew Products, Englewood Cliffs, NJ: Prentice-Hall, Inc.

Urban, Glen L., John R. Hauser, and John H. Roberts (1990), “Prelaunch Forecasting of New Automobiles", M anagement Science, 36 (4): 401-421.

Urban, Glen L., John R. Hauser, and Bruce Weinberg (1992), “Time Flies When You're Having Fun: How Consumers Allocate Their Time When Evaluating Products", Sloan School of Management Working Paper \#68-92.

Ward, Scott and Dave Reibstein (1979), N ote on M arket and Consumer Research, Cambridge, MA: Harvard Business School, 12 pp.

Winski, J. M. (1990), "Research + 'Creative Leap' = Award-winning Ads" Advertising A ge, September 24, p. 24. 


\section{Appendix A: Marketing Research References, Directories, and Guides}

Findex, The W orldwide D irectory of M arket Research Reports, Studies and Surveys (Cambridge Information Group, Bethesda, MD). Annual/ semiannual update. A reference guide to published, commercially available market and business research. A pproximately 12,500 reports from over 500 research publications are arranged by 12 industry categories.

Focus Groups: A Guide for M arketing and Advertising Professionals (Probus Publishing Company, Chicago, IL) 1987. A highly readable discussion of focus groups. Includes a series of appendixes that give samples of a six-week project timetable, respondent screening criteria, a moderator discussion guide, and a moderator transcript.

GreenBook International Directory of $M$ arketing Research Companies and Services (American Marketing Association/ New York Chapter, Inc., New York, NY). A nnual. A listing of market research companies arranged al phabetically, with brief paragraphs that describe the companies' services. Additional sections list the companies by type of service offered, by market/ industry specialty, by computer programs used, by company trademarks/ service marks, by geographical area and by principal personnel.

M RA Blue Book Research Services Directory

(Marketing Research Association, Inc., Rocky Hill, CT). A nnual. More limited in scope that the GreenBook, this guide focuses on services and facilities of data collection companies, research companies and suppliers of related services (data processing, questionnaire coding, field management, etc.) who are members of MRA. Company listings are alphabetical within each geographic area, cross-referenced by the type of service or facility available.

Professional $M$ ail Surveys

(McGraw-Hill, Inc., New York, NY), 1970. A definitive reference on how to ensure that mail survey results are as dependable as possible. This book set the standards for mail surveys.

Research Alert

(Alert Publishing Company, Long Island City, NY). Twice monthly. A concise newsletter that summarizes consumer market information and trends. Includes Bureau of Census trend data, public and proprietary studies, media research findings, and more. 


\section{Standard Directory of Advertising Agencies}

(National Register Publishing Company, Inc., New Providence, NJ).

Twice yearly. The SDAA is the most comprehensive source of information on advertising agencies and public relations firms in the U.S. It lists about 9,700 agencies, their areas of specialty, key personnel, and clients serviced. It is arranged alphabetically and geographically. 


\section{Appendix B: Examples of Structured Questions Used in Questionnaires}

\begin{tabular}{|c|c|c|c|}
\hline $\begin{array}{l}\text { Question } \\
\text { Type }\end{array}$ & Example & Use $_{8}$ & Comments \\
\hline $\begin{array}{l}\text { Dichotomous } \\
\text { Category } \\
\text { Scale }\end{array}$ & $\begin{array}{l}\text { Do you currently own a cellular } \\
\text { phone? } \\
\text { Yes } \\
\text { No }\end{array}$ & $\begin{array}{l}\text { When information } \\
\text { naturally falls into two } \\
\text { categories }\end{array}$ & $\begin{array}{l}\text { Easy to ask and to } \\
\text { tabulate results; } \\
\text { Must have only two } \\
\text { possible responses; } \\
\text { often, "don't know", } \\
\text { "neither", or "both" } \\
\text { are legitimate } \\
\text { responses. }\end{array}$ \\
\hline $\begin{array}{l}\text { Multiple- } \\
\text { choice } \\
\text { Category } \\
\text { Scale }\end{array}$ & $\begin{array}{l}\text { How many miles do you commute to } \\
\text { work each way? } \\
\text { less than } 10 \\
10-20 \\
20-30 \\
30-40 \\
40+\end{array}$ & $\begin{array}{l}\text { Instead of open-ended } \\
\text { questions, whenever all } \\
\text { responses can be } \\
\text { determined beforehand }\end{array}$ & $\begin{array}{l}\text { Must be able to } \\
\text { anticipate and list all } \\
\text { possible responses; } \\
\text { Can use Chi-square } \\
\text { analysis for evaluating } \\
\text { differences in } \\
\text { responses. }\end{array}$ \\
\hline $\begin{array}{l}\text { Verbal Rating } \\
\text { Scale }\end{array}$ & $\begin{array}{l}\text { How helpful did you find the product } \\
\text { instructions? Were they: } \\
\text { Extremely helpful } \\
\text { Very helpful } \\
\text { Somewhat helpful } \\
\text { Slightly helpful } \\
\text { Not at all helpful }\end{array}$ & $\begin{array}{l}\text { For measuring product } \\
\text { attributes }\end{array}$ & $\begin{array}{l}\text { Can assign numerical } \\
\text { values and calculate } \\
\text { means, run analysis of } \\
\text { variance, etc.; } \\
\text { To interpret results, } \\
\text { use another product as } \\
\text { a benchmark. }\end{array}$ \\
\hline $\begin{array}{l}\text { Attitude } \\
\text { (Likert) Scale }\end{array}$ & $\begin{array}{l}\text { For each statement, please indicate } \\
\text { whether you: } \\
\text { Strongly agree } \\
\text { Agree } \\
\text { Neither agree nor disagree } \\
\text { Disagree } \\
\text { Strongly disagree }\end{array}$ & $\begin{array}{l}\text { Used over a series of } \\
\text { statements for generating } \\
\text { a composite of a } \\
\text { respondents' attitudes; } \\
\text { gets at degree of } \\
\text { agreement or } \\
\text { disagreement }\end{array}$ & $\begin{array}{l}\text { Easy to construct and } \\
\text { administer, but may be } \\
\text { difficult to interpret. }\end{array}$ \\
\hline $\begin{array}{l}\text { Semantic } \\
\text { Differential } \\
\text { Scale }\end{array}$ & $\begin{array}{l}\text { Please place an } X \text { in the box that best } \\
\text { represents your opinion of the } \\
\text { product: } \\
\text { Distinctive } \square \square \square \square \square \square \square \text { Ordinary }\end{array}$ & $\begin{array}{l}\text { Used over a series of } \\
\text { statements for generating } \\
\text { a composite "image } \\
\text { profile" of a product, } \\
\text { organization, or brand. }\end{array}$ & $\begin{array}{l}\text { Versatile and easy to } \\
\text { administer; } \\
\text { Choice of endpoint } \\
\text { descriptors can be } \\
\text { difficult. }\end{array}$ \\
\hline $\begin{array}{l}\text { Rank-order } \\
\text { Scale }\end{array}$ & $\begin{array}{l}\text { Please rank the following } \\
\text { characteristics from most important to } \\
\text { least important to you, with } 1 \text { being } \\
\text { the most important and } 4 \text { being the } \\
\text { least important: } \\
\text { Lightweight } \\
\text { Small enough to fit in a pocket } \\
\text { Attractive } \\
\text { Inexpensive }\end{array}$ & $\begin{array}{l}\text { For collecting and } \\
\text { comparing information } \\
\text { on a group of items } \\
\text { (products, characteristics, } \\
\text { etc.) }\end{array}$ & $\begin{array}{l}\text { Relatively easy to } \\
\text { administer and to } \\
\text { tabulate; } \\
\text { Does not reflect the } \\
\text { degree to which one } \\
\text { attribute is ranked } \\
\text { higher than another }\end{array}$ \\
\hline
\end{tabular}




\section{Appendix C: Guidelines for Writing Survey Questions}

\begin{tabular}{|c|c|c|}
\hline Incorrect wording & Correct wording & Comments \\
\hline What is your annual income? & $\begin{array}{l}\text { To better understand how reactions } \\
\text { to this new product differ among } \\
\text { people with different age, income, } \\
\text { and other characteristics, we need to } \\
\text { know the following. } \\
\text { What is your annual income? }\end{array}$ & $\begin{array}{l}\text { Respondents may be unwilling to } \\
\text { answer, or to answer accurately, a } \\
\text { personal question when it is not } \\
\text { explained how the data are to be used; } \\
\text { include a brief explanation to legitimize } \\
\text { the question. }\end{array}$ \\
\hline $\begin{array}{l}\text { What is the current rate you pay } \\
\text { per minute for cellular phone } \\
\text { service? }\end{array}$ & $\begin{array}{l}\text { Do you know the current rate you } \\
\text { pay per minute for cellular phone } \\
\text { service? }\end{array}$ & $\begin{array}{l}\text { Respondents may be uninformed; } \\
\text { wording should not imply that the } \\
\text { answer should be known; this encourages } \\
\text { respondents to answer, even when the } \\
\text { answer is unknown. }\end{array}$ \\
\hline $\begin{array}{l}\text { How many times within the last } \\
\text { year have you used your cellular } \\
\text { phone? }\end{array}$ & $\begin{array}{l}\text { How many times within the last } \\
\text { week have you used your cellular } \\
\text { phone? }\end{array}$ & $\begin{array}{l}\text { Respondents may be forgetful; word } \\
\text { questions so that they do not require the } \\
\text { respondent to recall too far into the past. }\end{array}$ \\
\hline $\begin{array}{l}\text { Do you own a (brand name) } \\
\text { cellular phone? }\end{array}$ & $\begin{array}{l}\text { What brand of cellular phone do you } \\
\text { own? }\end{array}$ & $\begin{array}{l}\text { Singling out a brand name in a question } \\
\text { can cause respondents to believe that the } \\
\text { company is the sponsor of the survey; } \\
\text { respondents tend to express more } \\
\text { positive feelings toward survey sponsors. }\end{array}$ \\
\hline $\begin{array}{l}\text { Do you agree that cellular phone } \\
\text { use contributes to brain cancer? }\end{array}$ & $\begin{array}{l}\text { For the following statement, please } \\
\text { indicate whether you: } \\
\text { agree strongly } \\
\text { agree somewhat } \\
\text { neither agree nor disagree } \\
\text { disagree somewhat } \\
\text { disagree strongly } \\
\text { Cellular phone use contributes to } \\
\text { brain cancer. }\end{array}$ & $\begin{array}{l}\text { Avoid leading or biased questions, where } \\
\text { the respondent is given a clue to the } \\
\text { "right" answer, or where approval or } \\
\text { disapproval is suggested. Yes/no } \\
\text { attitude questions have a tendency } \\
\text { toward bias. }\end{array}$ \\
\hline $\begin{array}{l}\text { How well do you like the } \\
\text { product's size and weight? }\end{array}$ & $\begin{array}{l}\text { How well do you like the product's } \\
\text { size? } \\
\text { How well do you like the product's } \\
\text { weight? }\end{array}$ & $\begin{array}{l}\text { Avoid double-barreled questions, that is, } \\
\text { questions that require two separate } \\
\text { responses. }\end{array}$ \\
\hline $\begin{array}{l}\text { When driving, do you frequently } \\
\text { use your cellular phone for } \\
\text { traveler information? }\end{array}$ & $\begin{array}{l}\text { When driving, how frequently do } \\
\text { you use your ce llular phone for } \\
\text { traveler information? } \\
\text { more than } 5 \text { times a week } \\
\text { 1-5 times a week } \\
\text { fewer than once a week } \\
\text { never }\end{array}$ & $\begin{array}{l}\text { Use clear, unambiguous words; words } \\
\text { like "usually", "regularly" and } \\
\text { "frequently" are open to wide } \\
\text { interpretation and should be defined. }\end{array}$ \\
\hline
\end{tabular}


Appendix D: Comparison of Simulated and Full-scale Test Markets

\begin{tabular}{|c|c|c|}
\hline & Simulated Test Market & Full-scale Test Market \\
\hline Primary Objective & $\begin{array}{l}\text { Provides diagnostic information to } \\
\text { improve performance }\end{array}$ & Provides sale volume forecast \\
\hline Secondary Objectives & Provides sale volume forecast & $\begin{array}{l}\text { Provides diagnostic information to } \\
\text { improve performance } \\
\text { Provides reaction of the trade }\end{array}$ \\
\hline Time & IO-14 weeks & 6 mos. - 1 yrt \\
\hline $\cos t$ & $\$ 30-50,000$ & $\$ 500,000$ - $\$ 3$ million + \\
\hline Sample & $\begin{array}{l}200 \text { - } 600 \text { carefully-chosen } \\
\text { respondents }\end{array}$ & $\begin{array}{l}\text { one or more test cities that } \\
\text { represent, as nearly as possible, } \\
\text { the consumers and the marketing } \\
\text { conditions that represent the } \\
\text { whole U.S. }\end{array}$ \\
\hline Advantages & $\begin{array}{l}\text { Maintains confidentiality from } \\
\text { competitors }\end{array}$ & Real world; better at forecasting \\
\hline Disadvantages & $\begin{array}{l}\text { Only good at predicting sales if } \\
\text { estimated level of marketing } \\
\text { support is maintained during } \\
\text { national rollout } \\
\text { Not real world; competitive } \\
\text { reaction and trade reaction cannot } \\
\text { easily be predicted }\end{array}$ & $\begin{array}{l}\text { Only good at predicting sales if } \\
\text { estimated level of marketing } \\
\text { support is maintained during } \\
\text { national rollout } \\
\text { Competitors can audit and } \\
\text { sabotage results } \\
\text { Full control over variables is not } \\
\text { possible; more difficult defining } \\
\text { cause and effect }\end{array}$ \\
\hline Other & $\begin{array}{l}\text { Requires final product, package, } \\
\text { advertising etc. }\end{array}$ & $\begin{array}{l}\text { Requires final product, package, } \\
\text { advertising; etc. }\end{array}$ \\
\hline
\end{tabular}

